\title{
Islam, religiosity, and immigrant political action in Western Europe
}

\author{
Aida Just ${ }^{\mathrm{a}, *}$, Maria Elena Sandovici ${ }^{\mathrm{b}}$, Ola Listhaug ${ }^{\mathrm{c}}$ \\ a Political Science Department, Bilkent University, Turkey \\ ${ }^{\mathrm{b}}$ Political Science Department, Lamar University, United States \\ ${ }^{\mathrm{c}}$ Department of Sociology and Political Science, Norwegian University of Science and Technology (NTNU), Norway
}

\section{A R T I C L E I N F O}

\section{Article history:}

Received 2 April 2012

Revised 31 August 2013

Accepted 23 September 2013

Available online 2 October 2013

\section{Keywords:}

First and second generation immigrants

Political participation

Religion and Religiosity

Islam

Reactive identity

\begin{abstract}
A B S T R A C T
The issues of migration and immigrant political integration in western democracies have become increasingly intertwined with debates on religion, particularly Islam. To date, however, we have surprisingly little systematic research on how religious beliefs are related to immigrants' political engagement. In this study, we argue that religion has a capacity to mobilize immigrants politically but the strength of this relationship depends on immigrant generation, religiosity, and the type of religion. Using survey data collected as part of the European Social Survey (ESS) 2002-2010 in 18 West European democracies, our analyses reveal that religion is indeed linked to political engagement of immigrants in a complex way: while belonging to a religion is generally associated with less political participation, exposure to religious institutions appears to have the opposite effect. Moreover, we find that, compared to foreign-born Muslims, second-generation Muslim immigrants are not only more religious and more politically dissatisfied with their host countries, but also that religiosity is more strongly linked to their political engagement. This relationship, however, is limited to uninstitutionalized political action.
\end{abstract}

(C) 2013 Elsevier Inc. All rights reserved.

\section{Introduction}

International migration has altered the social make up of western democracies. Many European countries, such as Austria, Switzerland, Luxembourg, Ireland, Germany, and Sweden, now record proportions of foreign-born residents as high as or even higher than in traditional immigration countries, like the United States (Lemaitre and Thoreau, 2006). While some foreigners arrive from the EU member states, others come from increasingly more distant and diverse countries, contributing to the growing cultural and religious diversity of immigrant receiving nations (Castles and Miller, 2009). One consequence of international migration over the last few decades is that Muslims have become the largest religious group beside Christians among immigrants in Europe. According to 2010 Pew Research Center estimates, Europe (excluding Turkey) is now home to 44.1 million Muslims (about 6\% of the total population), up from 29.6 million in 1990 (Pew Research Center, 2011, p. 121). ${ }^{1}$

The growing share of immigrants with distinct religious beliefs has upended many comfortable and well-worn practices and ways of thinking in western democracies, and has challenged governments to contend with the practicalities of accepting and integrating immigrants. Tensions have arisen over such issues as the place of religion in the public sphere of society, the rights and obligations of immigrants, their commitment to democratic governance and gender equality, as well as links to religious extremist and terrorist organizations. These issues have taken on increased significance over time, as religiosity

\footnotetext{
* Corresponding author. Fax: +90 3122902742.

E-mail address: aidap@bilkent.edu.tr (A. Just).

1 In comparison, North America hosts 3.5 million Muslims (or 1\% of its total population) (Pew Research Center, 2011, p. 140).
} 
among Muslims in Western democracies has been found to be resilient across generations, with some second-generation immigrants embracing their religious identities even stronger than their foreign-born parents (Voas and Fleischmann, 2012). Moreover, a number of recent events - for example, the 2006 protests against the Danish cartoons, mass rallies in support of women's right to wear veils in public, lobbying for building new mosques, and even the 2005 London bombings, to name a few ${ }^{2}$ - all suggest that religious beliefs may play a role in motivating political action among newcomers in many contemporary democracies.

Although immigrant political engagement in Europe has become the focus of growing scholarly literature in recent years, in large part because of the availability of the European Social Survey data since 2002 (e.g. Just and Anderson, 2012; de Rooij, 2012; Alesina and Giuliano, 2011; Wright and Bloemraad, 2012; Aleksynska, 2011; Voicu and Şerban, 2012), there is surprisingly little systematic research on the role that religion plays in shaping immigrant political behavior. Specifically, while some scholars take into account respondents' belonging to some religious denominations (e.g. Alesina and Giuliano, 2011; Aleksynska, 2011; Voicu and Şerban, 2012), ${ }^{3}$ no studies to our knowledge simultaneously analyze the consequences of religion in a form of religious beliefs, religiosity, and exposure to religious institutions in shaping immigrant political participation in Europe. Moreover, scholars usually focus either on foreigners (e.g., Just and Anderson, 2012; Aleksynska, 2011; de Rooij, 2012), or second-generation immigrants (e.g., Alesina and Giuliano, 2011; Fleischmann et al., 2011), but rarely both, ${ }^{4}$ preventing us from systematic comparisons across immigrant generations. As a consequence, we do not know with much certainty whether believers among immigrants in Europe engage in politics more or less than secular immigrants do, whether this is equally true across immigrant generations and religious groups, and whether these differences - if they in fact exist - are affected by the nature and intensity of religious beliefs, exposure to religious institutions, immigrant experiences with their host and origin countries, or by something else entirely.

Below, we address these questions by examining the role of religion, particularly Islam, in motivating political participation among immigrants in West European democracies. We argue that religion has the capacity to mobilize immigrants politically but the strength of this relationship depends on immigrant generation, religiosity, and the type of religion. We test our arguments using cross-national and individual-level data collected as part of the European Social Survey (ESS) 2002-2010 in 18 West European democracies. Our analyses reveal that religion is indeed linked to political participation of immigrants in a complex way: while belonging to a religion is generally associated with less political participation, exposure to religious institutions has the opposite effect. Moreover, we find that, compared to foreign-born Muslims, second-generation Muslim immigrants are not only more religious and more dissatisfied with their host countries, but also that religiosity helps to activate their political engagement. This relationship, however, is limited uninstitutionalized forms of political action.

Our study contributes to scholarly literature in several ways. First, on a theoretical level, we highlight the complex yet important role that religion plays in shaping immigrants' political engagement in contemporary democracies. In doing so, we seek to contribute to a relatively slim body of cross-national research on when and how religion matters in politics (Bellin, 2008; Wald and Wilcox, 2006; Grzymala-Busse, 2012). Second, we go beyond extant studies by systematically analyzing the consequences of religion in the form of individuals' religiosity, exposure to religious institutions, and religion type, and test their consequences on political engagement among first- and second-generation immigrants. Third, by distinguishing theoretically and empirically between different kinds of political acts, we extend the scholarly focus beyond electoral participation - a type of political action most immigrants are not entitled to - and develop a more comprehensive understanding of the determinants of immigrant political engagement. Finally, our analysis goes beyond existing studies, which tend to focus on one or a small number of countries or cities, and puts existing arguments to a more demanding empirical test against a varied and extensive sample of European states with diverse immigrant groups and sizable Muslim populations.

Our paper proceeds as follows: in the next sections, we formulate and develop our argument; we then describe our data and measures, present analyses and results, and finally conclude by discussing the implications of our findings and offering suggestions for further research.

\footnotetext{
${ }^{2}$ We do not claim that these events are in any way representative of Muslim political participation or that some acts, such as protests against the Danish cartoons, were exclusive to or more prominent in West European democracies than elsewhere in the world. Instead, our only intention here is to highlight some of the more publicized events where immigrants' political engagement appears to be linked to religious beliefs, suggesting that the relationship between religion and immigrant political activism deserves a closer investigation.

3 For example, in analyzing political participation among second-generation immigrants, Alesina and Giuliano (2011) control for being a Catholic, Protestant, and Orthodox, but do not account for Muslims or individuals belonging to other faiths. Instead, the authors combine non-religious and other believers into a single category and treat them as a reference group for the three Christian denominations. In a study of immigrant engagement in voluntary associations, Voicu and Şerban (2012) similarly identify Protestants and Catholics, while treating all other respondents (both secular individuals and respondents belonging to other religions, including Muslims) as a reference category.

${ }^{4}$ Voicu and Şerban (2012) is one such exception, as their study identifies first- and second-generation immigrants, and analyzes them along with natives. However, the focus of their study is limited to engagement in voluntary associations, and it is unclear to what extent their findings generalize to a wider range of political activities. Moreover, while their empirical models account for differences in the levels of participation of first- and second-generation immigrants in comparison to natives, they do not systematically analyze variation in the slopes of their independent variables across immigrant generations. As a consequence, we do not know, for example, whether religion is more strongly linked to political participation among second-generation immigrants as opposed to foreignborn.
} 


\section{Religion and political engagement}

Studies of political participation have long acknowledged that individuals do not participate if they cannot, do not want to, or if nobody asked (Verba et al., 1995; Brady et al., 1995; Leighley, 1995). Religion matters for political participation because it has consequences for each of these considerations, although not always in the direction that enables political action. We posit that, generally speaking, while religion is linked to resources and mobilization networks that facilitate political participation, it is also associated with a worldview that may give priority to religious life over worldly affairs, creating fewer motivations for believers to engage in politics compared to secular individuals. The overall relationship of religion to political engagement depends on the strength of these competing forces.

Existing research tends to emphasize the resource and mobilization aspects of religion and considers religion as a classic predictor of political engagement. Theories of electoral behavior based on social cleavages suggest that political parties mobilize voters along religious lines (Lipset and Rokkan, 1967; Miller and Shanks, 1996; Converse, 1974; Lijphart, 1979). Disagreements over moral issues, doctrinal conflicts among different denominations, and introduction of compulsory secular education in the aftermath of the French Revolution gave rise to important Christian Democratic parties that sought to defend religious values and the moral authority of religious institutions in western democracies. These parties grew into broad mass movements after the introduction of universal suffrage and were able to claim the loyalties of remarkably high proportions of the churchgoers in the working class, particularly among women (Lipset and Rokkan, 1967, p. 15). Although secularization has eroded much of the traditional social base of these parties, religious cleavage remains a considerable force in structuring party politics and voting behavior (Minkenberg, 2010; Knutsen, 2004). ${ }^{5}$

The link between religion and political action, however, is not limited to the mobilizing efforts of political parties. Research from the United States reveals that religious organizations also play a central role. Some studies demonstrate that religious institutions increase people's engagement in politics because they help individuals develop resources - civic skills, political efficacy, and political knowledge - that enable their political participation (Verba et al., 1995; Brady et al., 1995; Jones-Correa and Leal, 2001). Others reveal that religious organizations are important because they create social networks, norms, and expectations that encourage participation, and sometimes directly recruit members into political action, as was the case with African American churches at the time of the civil rights movement (e.g., Djupe and Grant, 2001; Peterson, 1992; Harris, 1994; Norris, 2002, Ch. 9). ${ }^{6}$

Whether these findings extend to countries outside the United States has been questioned by subsequent research, however. A number of scholars point out that the United States is an exceptional case among western democracies due to its high levels of religiosity, vigorous competition among religious groups, and the fact that being religious is closely linked to American identity (cf. Voas and Fleischmann, 2012, pp. 529-530; Foner and Alba, 2008). As a consequence, while religious organizations play an important role in facilitating immigrants' integration (Hirschman, 2004) and stimulating their civic and political engagement in the United States (Jamal, 2005; Foley and Hoge, 2007), they may be less able or motivated to play this role in predominantly secular countries where religious identities and symbols are seen with unease in the public sphere (e.g., Cesari, 2004).

Nevertheless, there are reasons to expect that religious institutions play an important role in mobilizing immigrants for political action in Western Europe as well. Research shows that European governments have increasingly engaged in a formal dialogue with religious leaders to promote integration and peaceful coexistence of different religions (Klausen, 2005; Permoser et al., 2010; Laurence, 2006). These official efforts to cooperate combined with the ability of religious institutions to provide believers with resources, networks, and political cues, suggest that people's exposure to religious institutions should be associated with higher levels of their engagement in political action. We therefore hypothesize that attendance of religious services should contribute positively to immigrants' political participation in their host societies (Hypothesis 1).

While exposure to religious institutions can be expected to increase people's participation in politics, belonging to a religion may have the opposite effect. Research on Muslim political participation indicates that some Muslims deliberately refrain from political action because they consider it as Haram (forbidden) for believers (Hopkins and Kahani-Hopkins, 2004). Specifically, some Muslims perceive political participation in western democracies as a challenge to the Quran's teaching that believers are forbidden to accept the authority of the disbelievers over them. The act of voting in secular societies is seen as particularly subversive to Muslim identity because it signals direct engagement with the political system of nonbelievers. ${ }^{7}$

A negative relationship between religious affiliation and political action may not be limited to Muslims if we consider that religious affiliation encourages people to value godly matters above world affairs, and to view religious life as an alternative to political participation (e.g., Barnes et al., 1979, pp. 118-119). ${ }^{8}$ Consistent with this perspective, literature on social

\footnotetext{
5 The role that political parties play in mobilizing political engagement among immigrants is less clear, as many immigrants, especially foreign-born individuals, do not have citizenship, cannot vote in national elections, and therefore cannot provide immediate electoral support for political parties competing for public office at the national level.

6 Religious organizations have been regarded as particularly important for individuals of low socio-economic status and minority groups that might otherwise be more marginalized politically (Brady et al., 1995; Norris, 2002, p. 220). Consistent with this perspective, Voicu and Şerban (2012) found that immigrants are more likely to join religious organizations than other voluntary associations.

7 This issue, however, remains contentious among Muslims, with some arguing in favor of political engagement as a way to express their legitimate interests and improve their situation in host societies (Hopkins and Kahani-Hopkins, 2004; Ramadan, 2004).

${ }^{8}$ Historically, political disengagement of pious individuals in Europe was reinforced by the Catholic Church, which initially had a strong distaste for political parties and popular mobilization, in part because they challenged the church's hierarchical control over Catholics (Kalyvas, 1996).
} 
movements points out that religious individuals tend to prioritize immediate religious concerns over political engagement, except when they feel compelled to react to attacks on sacred-values and anti-religious practices that interfere with their ability to live godly lives (e.g., Wald et al., 2005, p. 130; see also McVeigh and Sikkink, 2001). Other studies also show that religious individuals believe that the world is just and that people generally get what they deserve (Benabou and Tirole, 2006; Scheve and Stasavage, 2006). This view suggests that believers may be less inclined to blame governments for social ills and economic failures than secular individuals, and consequently may be less motivated to engage in politics as a way to reward or punish political actors for their performance while in office. Our second hypothesis (Hypothesis 2) is therefore that believers should be less politically engaged than secular individuals.

\section{Islam, religiosity, and second-generation immigrants}

Whether as a consequence of decolonization, political unrest, or economic hardships in Northern Africa, South East Asia, and the Middle East, Muslims have become the largest religious group beside Christians among immigrants in Europe (Pew Research Center, 2011). Practicing Islam - a religion that is often seen as foreign or "imported" by Europeans (Eggert and Giugni, 2011) - requires a number of special provisions such as permitting religious clothing and symbols in public places, establishing new mosques and Islamic cemeteries, as well as ensuring access to faith-based education, to name a few (e.g., Maussen, 2007; Buijs and Rath, 2006; Nielsen, 1999). Although European countries vary in the degree to which they have been able to accommodate Islam (e.g., Fetzer and Soper, 2005; Koenig, 2005), Muslims still face many challenges in a widely secularized and traditionally Christian environment that characterizes established democracies in Europe (Foner and Alba, 2008; Buijs and Rath, 2002).

Considering the outsider status and lack of accommodation of Islam in Western Europe, Muslim immigrants may feel more alienated from the politics of their host societies and therefore participate in politics less than Christian immigrants. At the same time, however, we would expect considerable heterogeneity within religious groups, as not all believers are equality motivated or able to engage politically. Since securing an institutional and cultural environment in which Muslims can properly practice their faith should be more important for Muslims who are highly religious, we expect religiosity to interact with Muslim identity. This means that religiosity should increase the positive effect (or at least reduce the negative effect) that belonging to Islam may have on immigrant engagement in politics of their host societies (Hypothesis 3).

Furthermore, we posit that the propensity of religious Muslims to engage politically should be more pronounced among second-generation immigrants, as they possess more resources and stronger motivation to achieve their policy goals than foreign-born individuals. Specifically, being born and socialized in their host country, second-generation immigrants are likely to have a better understanding of the rules and regulations governing their country's politics and of the ways in which ordinary individuals can influence the political process. In addition, they tend to be more proficient in the official language and may have more opportunities for political engagement in comparison to foreign-born individuals whose immediate concerns of getting settled - finding housing and employment - may leave little time for other activities.

Better skills and resources, however, are only one part of the story in our explanation why second-generation immigrants should engage in political action more than foreign-born individuals. Another part has to do with motivation resulting from a sense of entitlement among locally born immigrants. In contrast to first-generation immigrants who typically arrive with positive attitudes towards their host countries due to their self-selection into migration (Maxwell, 2010; see also Dancygier and Saunders, 2006), by definition, second-generation immigrants did not choose to migrate - they were born in their host countries. The native status makes them feel more entitled to the same treatment as majority populations, and less inclined to tolerate discrimination, social marginalization, and injustice than first-generation immigrants. Existing research shows that second-generation Muslim immigrants in Europe indeed report higher levels of perceived discrimination than foreign-born Muslims do (cf., Voas and Fleischmann, 2012, p. 536).

While grievances might have a direct effect on political action, as some traditional accounts of protest activity suggest (e.g. Gurr, 1970), perceptions of unfair treatment and social exclusion may also operate on political participation indirectly, that is, via reactive religious identity. The idea of reactive identity is not new in social science research. Scholarly literature on immigrant integration in the United States developed the notion of reactive ethnicity, suggesting that group consciousness among second-generation immigrants increases in response to social marginalization (Portes and Rumbaut, 2001; Kurien, 2005; Portes and Zhou, 1993). The notion of reactive identity has been subsequently extended to the religious domain, and evidence of reactive religiosity was found both in the United States and Europe (Haddad, 2007; Diehl and Koenig, 2009; Peek, 2005; Open Society Foundation, 2011; Fleischmann et al., 2011). For example, Diehl and Koenig (2009) reveal that religious identity is remarkably resilient among Turkish immigrants in Germany, and find support for the theory of religion as a compensatory strategy among socially marginalized second-generation immigrants. Perceptions of discrimination were found to also contribute to a strengthened Muslim identity among European-born Turkish and Moroccan immigrants in urban areas of Belgium, Sweden, and the Netherlands (Fleischmann et al., 2011), although there is some evidence that this relationship weakens when childhood religious socialization is taken into account (Fleischmann and Phalet, 2012). Similarly, interviews with Muslim women in France showed that the majority of second-generation Muslim women chose to wear the veil as a reaction to the debates over head scarves in public spaces (Open Society Foundation, 2011). ${ }^{9}$

\footnotetext{
${ }^{9}$ The adoption of the headscarf among young Muslim women reportedly has also increased in the United States after September 11, 2001 as a symbol of allegiance to Islamic identity (Haddad, 2007; Peek, 2005).
} 
These results are consistent with a more general finding in the literature on social psychology that experiences of discrimination strengthen identification with the threatened in-group as a way for devalued group members to counteract the negative consequences discrimination has on their self-esteem (e.g., Branscombe et al., 1999; Schmitt and Branscombe, 2002). Religious identity is particularly well suited to enhance individuals' subjective well-being due to the fact that it offers a comforting and compelling worldview, a robust social support system, and a unique form of psychological enrichment (Ysseldyk et al., 2010, p. 67). Consistent with this view, a number of studies documented that Muslims' perceptions of unfair treatment and social exclusion in Europe revitalize religious identity among second-generation immigrants (Fleischmann et al., 2011; Diehl and Koenig, 2009; Verkuyten and Yildiz, 2007; but see Fleischmann and Phalet, 2012), and consequently strengthen their readiness to engage in political action to defend Islamic values (Fleischmann et al., 2011, p. 641). ${ }^{10}$ Drawing on insights from this literature, we therefore hypothesize that the positive relationship being a religious Muslim and political engagement should be more pronounced among second-generation immigrants than among foreign-born individuals (Hypothesis 4).

\section{The varieties of political action}

While early studies of political participation in democracies focused mostly on understanding standard modes of political engagement, such as electoral participation, the scope of inquiry into political engagement widened considerably in the aftermath of popular unrest during the 1960s and 1970s, as researchers began to take into account a broader repertoire of political acts, including protest behavior. This expansion of focus brought with it the conceptual distinction between the traditional conventional, institutionalized acts of participation on the one hand, and unconventional, uninstitutionalized, acts on the other (Barnes et al., 1979; Muller, 1979). Institutionalized action is usually defined as involving routine political acts (mostly) oriented toward the electoral processes, while uninstitutionalized participation is conceptualized as taking place outside of electoral politics and often involving more spontaneous, episodic, and disruptive political acts (Kaase, 1989).

Considering the options for political engagement available to individuals, one important question is what motivates any particular act. Traditionally, in the context of established democracies, conventional political activities such as voting have been viewed as acts that affirm individuals' allegiance to the political system. Consistent with this view, considerable evidence shows a strong correlation between positive attitudes about politics and the political system on one hand and participation in conventional political activities on the other (Leighley, 1995; Rosenstone and Hansen, 1993; Finkel, 1985; Verba et al., 1978). Conversely, a number of studies have found that mistrust and political grievances increase engagement in unconventional political acts (Gamson, 1968; Muller, 1977; Milbrath and Goel, 1977). Moreover, the connection between political discontent and unconventional participation appears to be particularly pronounced among political and ethnic minorities (Craig and Maggiotto, 1981; Shingles, 1981). This finding is consistent with the idea that unconventional politics has traditionally provided an outlet for disadvantaged minorities, as well as other groups that lack access to politics through conventional channels and are alienated from the established political order (Dalton, 2006, pp. 62-63). And while uninstitutionalized political action has broadened from the disadvantaged to include a wider spectrum of society (Van Aelst and Walgrave, 2001; Norris, 2002, p. 201) and has become an accepted form of engagement in contemporary democracies (Barnes et al., 1979; Meyer and Tarrow, 1998), it remains a powerful tool for the expression of grievances among disaffected minorities as it conveys high levels of information with real political force (Dalton, 2006, Ch. 3). ${ }^{11,12}$

In light of this literature and the fact that Muslims remain a distinct minority in largely secularized and traditionally Christian West European societies, we hypothesize that being a religious Muslim should be more strongly linked to uninstitutionalized than institutionalized political acts (Hypothesis 5). This means that we should observe a positive and statistically significant coefficient of the interaction between religiosity and Islam in the models of uninstitutionalized political action, and a substantively weaker or statistically insignificant estimate of this interaction in the models of institutionalized political acts.

\section{Data and measures}

The individual level data employed in our analyses come from the European Social Survey (ESS) collected 2002-2010 (1-4 round cumulative file) (Jowell et al., 2007). The ESS project is known for its high standards of methodological rigor in survey design and cross-national data collection (Kittilson, 2009). ${ }^{13}$ Strict random sampling of individuals regardless of nationality, citizenship, language, or legal status is used to ensure representativeness of national populations. ${ }^{14}$ Moreover, our analyses

\footnotetext{
${ }^{10}$ Interestingly, research from the United States indicates with growing religious diversity religion has replaced ethnicity as the most important identity marker for the second and higher generations among the post-1965 immigrants (Ebaugh and Chafetz, 2000; Jeung et al., 2012; Peek, 2005).

11 To say that individuals who previously participated in politics via institutionalized channels now also do so via less institutionalized forms of political action is not to say that disadvantaged minorities have similarly expanded their repertoire of political action from less to more institutionalized participation. For disadvantaged minorities, contentious political action may still be their primary route of communicating their demands to policy makers.

12 To be sure, being disaffected or holding grievances is a necessary but not a sufficient condition for an individual's engagement in protest behavior (McAdam et al., 1996; McAdam et al., 2010). Research shows that only a small proportion of the people holding grievances participate, as engagement in contentious action depends on individual and organizational resources (Dalton, 2006; Van Aelst and Walgrave, 2001; Norris, 2002, p. 201; McCarthy and Zald, 1977), emancipative values (Inglehart and Welzel, 2005; Welzel and Deutsch, 2011), the nature of a movement, political opportunity structures, and macro-economic development (Eisinger 1973; McAdam, 1982; Meyer, 2004, 2006; Dalton et al., 2010; Dalton and Van Sickle, 2005; Kitschelt, 1986; Giugni, 2007).

${ }^{13}$ It is based on hour-long face-to-face interviews and survey questions designed for optimal cross-national comparability.

14 We base our analyses on respondents aged 18 or older to ensure that they are of legal age to engage in all forms of political acts. Estimating our models using all respondents (that is, aged 15 or older), however, does not change our findings.
} 
reveal that the ESS data are highly representative of immigrant populations as well. ${ }^{15}$ In addition, this collaborative project is the only set of cross-national surveys that include questions designed specifically for immigrants as well as standard items measuring respondents' religiosity, religion, attendance of religious services, and political participation. Finally, it is the only set of surveys that ask these questions in identical format across a broad range of countries. The relevant survey items were available for 18 West European democracies: Austria, Belgium, Switzerland, Cyprus, Germany, Denmark, Finland, France, Great Britain, Greece, Ireland, Italy, Luxembourg, the Netherlands, Norway, Portugal, Spain, and Sweden. In the sections to follow we include short descriptions of the main groups of variables. These are primarily items from the survey questionnaires, but we also include macro variables as they are relevant to test hypotheses about effects of country characteristics.

\section{Dependent variables}

To account for the varieties of political action and also for the fact that the number of political acts people engage in is relatively low, we measured political participation in several ways. First, we constructed an additive index based on whether a respondent reported having done the following over the course of the last year: contacted a politician or government official, worked in a political party or action group, worked in another organization or association, signed a petition, took part in a lawful public demonstration, and boycotted certain products. ${ }^{16}$ The index ranges from 0 to 6 , with higher values indicating more political engagement.

Since we hypothesized that the effects of religion will vary across different types of political action, we also separate the index of participatory acts into institutionalized and uninstitutionalized forms of political action (following the distinction made by Barnes et al., 1979, pp. 59-60; see also Dalton, 2006). Institutionalized political action is measured by an additive index of the following three activities respondents reported having engaged in during the last year: contacted a politician or government official, worked for a political party or action group, and worked for another organization or association. The uninstitutionalized participation index is similarly based on the following three types of political acts: signed a petition, took part in a lawful demonstration, and boycotted products. Both measures of participation range from 0 to 3 , with higher values indicating more political engagement.

\section{Independent variables}

We rely on several survey items to measure people's religious beliefs. First, respondents were asked if they consider themselves as belonging to any particular religion or denomination. If they said "yes", they were then asked to specify their religion or denomination. Using responses to these questions, we created dichotomous variables for Christians, Muslims, and other religions, and relied on non-religious as a reference category for religious groups in our empirical analyses. Further, we measure respondents' religiosity using the following survey question: "Regardless of whether you belong to a particular religion, how religious would you say you are?" Responses to this question were coded on a scale from 0 to 10 , with higher values indicating stronger religiosity. Finally, to capture the exposure to religious institutions, we relied on the following survey item: "Apart from special occasions such as weddings and funerals, about how often do you attend religious services nowadays?" We have reversed the original coding categories of this variable so that it ranges from 0 (never) to 6 (every day), that is, with higher values indicating more frequent attendance of religious services.

To examine whether immigrant generation interacts with religion and religiosity in shaping political participation, we distinguish between first- and second-generation immigrants. First-generation immigrants were identified using the survey question "Were you born in this country?" and coded 1 if respondents reported being foreign-born, 0 - otherwise. ${ }^{17}$ Secondgeneration immigrants are individuals who reported that they were born in their country of residence but whose one or both parents were foreign-born.

\section{Control variables}

Our statistical analyses control for a range of variables identified as consistent determinants of political participation in past research. Since the research literature on political action is huge, we must limit our review to some of the standard

\footnotetext{
15 We calculated the percentages of foreign-born respondents in the ESS sample and compared these to data measuring the actual percentages of foreign-born individuals from the 2001 Census data, available from the European Union's statistical agency, Eurostat. The Pearson correlation between the percentages of foreign-born individuals in the surveys and foreign-born residents according to Eurostat Census figures in the countries included in our study was 0.98, indicating an extremely close fit between survey and official statistics. Secondly, using a question about respondents' country of origin, we examined the extent to which our samples of foreign-born respondents were representative of populations in the countries under investigation by calculating the percentages of individuals from different regions of the world: Africa, Asia, the Balkans, East Central Europe, Latin America, the Middle East, North America, Australia and New Zealand, and Western Europe. The Pearson correlation between the percentages of foreign-born individuals in our surveys from specific regions and the Eurostat data on foreign-born residents in the countries from these regions was 0.90 , indicating yet again a very close fit between survey and official statistics. For more details about individual countries, please contact the authors. Other studies that relied on ESS samples of immigrants to study their attitudes and behaviour include Wright and Bloemraad (2012), de Rooij (2012), Maxwell (2010), Just and Anderson (2012), Connor (2010), Alesina and Giuliano (2011), and Aleksynska (2011).

16 Voting turnout is not included because many foreign-born are not citizens and therefore do not have a legal right to vote in national elections.

17 Foreign-born with both native-born parents were excluded from the analyses, although doing so does not change our findings.
} 
arguments and main empirical contributions. Generally speaking, people are more likely to participate in a variety of modes of political action if they have the necessary resources and motivation to get involved. The most prominent proxy for resources has been socio-economic status (Verba et al., 1995), and a substantial literature documents that education and social status (measured by income or class) have a positive impact on political engagement across a variety of countries (Almond and Verba, 1963; Jennings et al., 1989; Nie et al., 1971). Participation also generally increases with age, although it declines slightly among the elderly (Verba and Nie, 1972). Furthermore, researchers have found that men are more likely to have the resources needed to engage in politics (Dalton, 2006), and that gender stereotypes have traditionally contributed to a greater proclivity of men to be politically involved (Hansen, 1997; Jennings, 1983).

In addition to standard demographic variables, our models include measures of social incorporation found to be important for political participation (Wolfinger and Rosenstone, 1980; Ramakrishnan, 2005, esp. Ch. 4). The unemployed tend to participate less not just because they tend to have lower incomes but also because they do not participate in social networks in the workplace that reward political participation. Further, marital status has been found to have the strongest effect on political involvement among those who only need a slight push to participate - for example, those with low levels of education (Wolfinger and Rosenstone, 1980). Moreover, we include a direct measure of social connectedness based on a survey item indicating how often a respondent meets socially with friends, relatives, or work colleagues (Bloemraad, 2006). To capture the effects of social and political grievances in motivating political action (Gurr, 1970; Bateson, 2012; Dalton et al., 2010; Dalton and van Sickle, 2005), we rely on measures of perceived discrimination, being a crime victim, satisfaction with the way democracy works in one's country, as well as the extremity of one's ideological views.

To account for immigrant-specific experiences, our models control for citizenship, as citizens are expected to be more engaged in the politics of their host countries due to lower costs and stronger motivation to participate (Just and Anderson, 2012; DeSipio, 1996). Length of stay in a host country also matters because it is associated with more exposure and familiarity with a political system, as well as a stronger sense of having a stake in the host country's politics, all of which stimulate civic and political action (White et al., 2008; Liang, 1994; Bueker, 2005; Bass and Casper, 2001; Aleksynska, 2011; Voicu and Şerban, 2012). Moreover, to control for foreigners' socialization experiences prior to arrival, we include a measure of the level of democracy in immigrants' countries of origin, as less democratic regimes usually provide their citizens with fewer opportunities to be socialized into democratic norms, a weaker sense of civic responsibility, and a lack of skills and knowledge necessary for political engagement in liberal democracies (White et al., 2008; Black, 1987; Black et al., 1987; Ramakrishnan, 2005, p. 91; Bueker, 2005). Finally, we include a dichotomous variable measuring whether an immigrant has one foreignborn parent as opposed to two foreign-born parents because immigrants with one native-born parent might be better integrated in their host society and consequently participate in politics more. Although we cannot include measures of all relevant background experiences of immigrants, we are confident that our indicators tap into the most relevant experiences identified by previous research.

At the macro-level, existing literature also suggests taking into account a country's level of economic development (measured by the GDP per capita) and economic performance (annual percentage of GDP growth), since participation rates and involvement tend to increase with higher levels of development and better economic conditions (Almond and Verba, 1963; Lipset, 1994; Norris, 2002; Dalton et al., 2010). Country's political opportunity structure in our sample of advanced industrialized democracies is captured using a measure of government effectiveness. We include this variable because people have been found to engage in political action more in countries where they perceive governments to be better capable of responding to public demands (Dalton and van Sickle, 2005). Finally, the size of foreigner population in a country is used to account for collective action problems in larger immigrant groups (Olson, 1971), while a country's average level of political participation is designed to capture the consequences of any remaining forces that generally shape political engagement of mass publics. Details on coding procedures for all variables are listed in the appendix.

\section{Analysis and results}

Combining information collected at the levels of individuals and countries means that our data has a multi-level structure (where one unit of analysis, the individual, is nested within another unit - the country). The results of a variance-components model (ANOVA) reveal that there is statistically significant variation in the levels of political participation at both micro and macro levels of analysis, suggesting that a multi-level model is preferred to an ordinary regression. ${ }^{18}$ To avoid a number of statistical problems associated with such a data structure, including clustering, non-constant variance, and incorrect (usually underestimated) standard errors (cf. Snijders and Bosker, 1999; Steenbergen and Jones, 2002), we rely on multi-level models with random intercepts (to account for cross-country heterogeneity in the levels of political participation) and immigrants nested within their countries of residence.

A first look at the data in Fig. 1 reveals that, consistent with previous research, the overall levels of political engagement are relatively low: the mean values are .920 for political action, and .386 and .535 - for institutionalized and uninstitutionalized participation in politics. However, examining political participation by immigrant generation reveals marked differences: while, on average, first-generation immigrants are least involved in (nonelectoral) politics (with a score of .737 on the political action scale), participation is significantly higher among second-generation immigrants (1.096), who engage

\footnotetext{
$\overline{18}$ Both variance components are statistically significant for all three dependent variables using full sample of respondents as well as in split sample estimations by immigrant generation (the results are available upon request from the authors).
} 


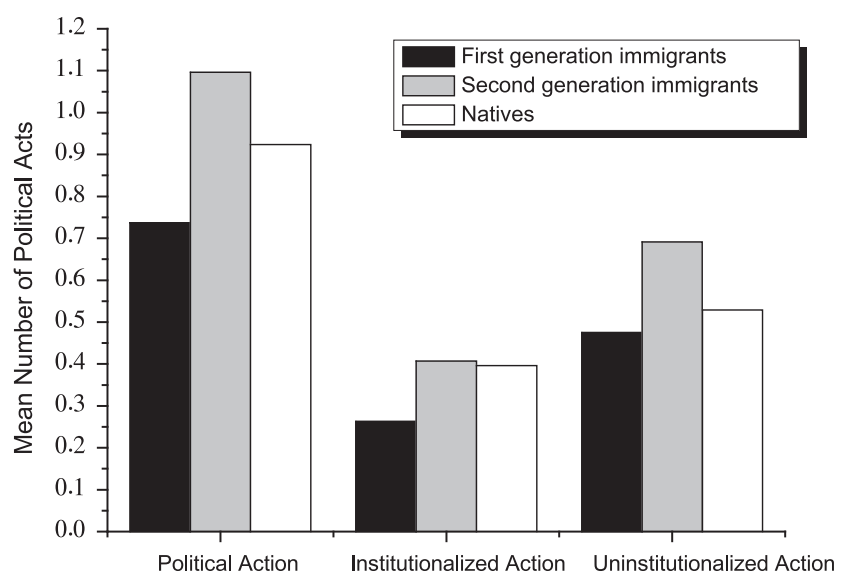

Fig. 1. Mean number of political acts by immigrant generation and action type in 18 West European democracies.

in politics even more than native populations (.924). Looking at the underlying distribution by action type indicates that high levels of political participation among second-generation immigrants are due to their high involvement in uninstitutionalized action: the mean value is .691 in comparison to .475 for foreign-born and .529 for natives. Engagement in institutionalized political acts is also the highest among second-generation immigrants (.407), but natives are only slightly behind (.396), while foreigners are least politically involved (.263). Overall, however, uninstitutionalized political participation is more widespread among immigrants of both generations as well as natives than institutionalized political action, and is particularly high among second-generation immigrants.

Descriptive statistics of our main independent variables among first- and second-generation immigrants show that, on average, Muslims are more religious than Christians: the mean values of religiosity are 6.832 for Muslims, 6.194 for Christians, while newcomers belonging to other religions fall in-between with a score of $6.272 .{ }^{19}$ Religiosity also varies by immigrant generation: foreign-born individuals are on average more religious (5.423) than second-generation immigrants (4.630). However, these numbers mask considerable differences between religious groups. Specifically, as Fig. 2 reveals, religiosity is higher among second-generation Muslim immigrants compared to foreign-born Muslims: the respective scores are 7.072 and 6.774. In contrast, the pattern is reversed when we compare first- and second-generation Christian immigrants: the respective values are 6.374 vs. 5.963 , and the same is true for other religions where the drop from the first- to the second-generation is even larger (6.431 vs. 5.722). Taken together, the descriptive statistics reveal that second-generation immigrants are more politically involved than foreigners (and natives), and that religiosity is higher among second- than first-generation Muslim immigrants, while the pattern with respect to religiosity is reversed among immigrants of other faiths.

To examine the links between religion, immigrant generation, and political participation with more precision, our analysis proceeds in three steps. First, we estimate our models using information for all respondents in all countries. We do so to establish a baseline for the impact of religion, religiosity, and exposure to religious institutions on political participation, and to see whether first- and second-generation immigrants are statistically distinguishable from the natives. As a second step, we turn exclusively to immigrants, and analyze whether the relationship between religion and political participation varies across immigrant generations. Specifically, we seek to assess whether religiosity is indeed more strongly linked to political engagement among second-generation Muslim immigrants than among foreign-born Muslims or newcomers of other faiths. Finally, we report the results by action type to test whether religion is more powerfully associated with immigrant engagement in uninstitutionalized than institutionalized political acts. It is worth noting that due to the difficulties in disentangling the reciprocal effects between religion and political engagement using our data, the results in this part should be interpreted as correlations rather than causal effects.

\section{Baseline models}

To assess the relationships between our key independent and dependent variables across all countries and all respondents in our base-line models, we include two dichotomous variables for first- and second-generation immigrants, using natives as the comparison group. ${ }^{20}$ The results, shown in Table 1 , indicate that political engagement is systematically lower among first-generation immigrants than among natives: the coefficient is statistically significant for the overall measure of political action as well as in the estimations by action type, but is particularly pronounced in the model of institutionalized participation. In contrast to foreigners, we find that second-generation immigrants are more politically engaged than native

\footnotetext{
19 The pattern in the overall sample of respondents is the same: the scores for Muslims, Christians, and other believers are 6.893, 6.035, and 6.230, respectively.

${ }^{20}$ We define natives as respondents who are native-born and whose both parents are native-born.
} 


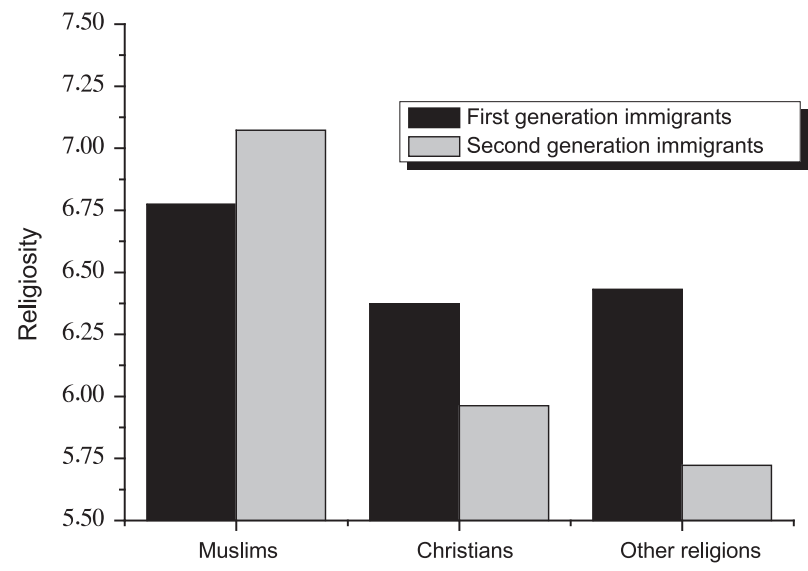

Fig. 2. Religiosity among first and second-generation immigrants by religion type in 18 West European democracies.

individuals: the estimate is statistically significant for the overall index of political action, although the results by action type indicate that this relationship is limited to uninstitutionalized political acts.

The results also show that religion plays a complex role in motivating political participation. We find that respondents who belong to Christianity or Islam - 98.83 percent of all believers in our sample - participate in politics less than secular

Table 1

Political participation in 18 European countries, 2002-2010.

\begin{tabular}{|c|c|c|c|c|c|c|}
\hline \multirow{2}{*}{$\begin{array}{l}\text { Independent variables } \\
\text { First-generation immigrant }\end{array}$} & \multicolumn{2}{|c|}{ Political action } & \multicolumn{2}{|c|}{ Institutionalized action } & \multicolumn{2}{|c|}{ Uninstitutionalized action } \\
\hline & $-.199^{* * *}$ & $(.019)$ & $-.119^{* * *}$ & $(.011)$ & $-.080^{* * *}$ & $(.012)$ \\
\hline Second-generation immigrant & $.063^{* * *}$ & $(.015)$ & -.003 & $(.009)$ & $.067^{* * *}$ & $(.010)$ \\
\hline Religiosity & $.003^{*}$ & $(.002)$ & $.003^{* * *}$ & $(.001)$ & .000 & $(.001)$ \\
\hline Muslim & $-.208^{* * *}$ & $(.037)$ & $-.069^{* *}$ & $(.023)$ & $-.135^{* * *}$ & $(.024)$ \\
\hline Christian & $-.079^{* * * *}$ & $(.009)$ & .002 & $(.006)$ & $-.082^{* * *}$ & $(.006)$ \\
\hline Other religion & $.187^{* * *}$ & $(.046)$ & $.076^{* *}$ & $(.027)$ & $.115^{* * *}$ & $(.030)$ \\
\hline Religious services attendance & $.049^{* * *}$ & $(.003)$ & $.039^{* * *}$ & $(.002)$ & $.011^{* * *}$ & $(.002)$ \\
\hline Citizen & $.217^{* * *}$ & $(.024)$ & $.100^{* * *}$ & $(.015)$ & $.118^{* * *}$ & $(.016)$ \\
\hline Social connectedness & $.085^{* * *}$ & $(.003)$ & $.049^{* * *}$ & $(.002)$ & $.036^{* * * *}$ & $(.002)$ \\
\hline Crime victim & $.246^{* * * *}$ & $(.009)$ & $.092^{* * *}$ & $(.005)$ & $.154^{* * *}$ & $(.006)$ \\
\hline Discriminated against & $.446^{* * *}$ & $(.016)$ & $.176^{* * *}$ & $(.010)$ & $.270^{* * *}$ & $(.010)$ \\
\hline Satisfaction with democracy & -.003 & $(.002)$ & $.004^{* * *}$ & $(.001)$ & $-.007^{* * *}$ & $(.001)$ \\
\hline Ideological extremity & $.080^{* * *}$ & $(.003)$ & $.034^{* * *}$ & $(.002)$ & $.045^{* * *}$ & $(.002)$ \\
\hline Male & $.055^{* * *}$ & $(.007)$ & $.125^{* * *}$ & $(.004)$ & $-.070^{* * *}$ & $(.005)$ \\
\hline Age & $.036^{* * *}$ & $(.001)$ & $.021^{* * *}$ & $(.001)$ & $.015^{* * *}$ & $(.001)$ \\
\hline Age squared & $-.000^{* * * *}$ & $(.000)$ & $-.000^{* * *}$ & $(.000)$ & $-.000^{* * *}$ & $(.000)$ \\
\hline Married & $.043^{* * *}$ & $(.008)$ & $.058^{* * *}$ & $(.005)$ & $-.016^{* *}$ & $(.005)$ \\
\hline Education & $.062^{* * *}$ & $(.001)$ & $.027^{* * *}$ & $(.001)$ & $.036^{* * *}$ & $(.001)$ \\
\hline Unemployed & $-.072^{* * * *}$ & $(.017)$ & -.016 & $(.010)$ & $-.056^{* * *}$ & $(.011)$ \\
\hline Income & $.013^{*}$ & $(.005)$ & $.019^{* * *}$ & $(.003)$ & -.006 & $(.003)$ \\
\hline GDP per capita (in 1,000 of \$'s) & $-.004^{*}$ & $(.002)$ & $-.002^{*}$ & $(.001)$ & $-.003^{*}$ & $(.001)$ \\
\hline Economic growth (\%) & .001 & $(.002)$ & .001 & $(.001)$ & .000 & $(.001)$ \\
\hline Government effectiveness & $.076^{* * * *}$ & $(.024)$ & .019 & $(.012)$ & $.040^{*}$ & $(.016)$ \\
\hline Foreign population size (\%) & $.007^{* *}$ & $(.002)$ & $.004^{* *}$ & $(.001)$ & $.004^{* *}$ & $(.001)$ \\
\hline Average political participation & $.820^{* * *}$ & $(.047)$ & $.881^{* * *}$ & $(.052)$ & $.886^{* * *}$ & $(.044)$ \\
\hline Constant & $-2.315^{* * *}$ & $(.087)$ & $-1.411^{* * *}$ & $(.043)$ & $-.918^{* * *}$ & $(.058)$ \\
\hline \multicolumn{7}{|l|}{ Variance components } \\
\hline Country level & .008 & $(.003)$ & .001 & $(.000)$ & .004 & $(.001)$ \\
\hline Individual level & 1.308 & $(.006)$ & .477 & $(.002)$ & .551 & $(.002)$ \\
\hline Number of observations & \multicolumn{2}{|c|}{98,876} & \multicolumn{2}{|c|}{99,438} & \multicolumn{2}{|c|}{99,042} \\
\hline Number of groups & \multicolumn{2}{|c|}{18} & \multicolumn{2}{|c|}{18} & \multicolumn{2}{|c|}{18} \\
\hline Wald $X^{2}(\mathrm{df})$ & \multicolumn{2}{|c|}{$12,129.9(25)^{* * *}$} & \multicolumn{2}{|c|}{$8371.2(25)^{* * * *}$} & \multicolumn{2}{|c|}{$10,458.4(25)^{* * *}$} \\
\hline
\end{tabular}

Note: Results are multi-level (random intercept) linear regression estimates (using STATA's xtmixed command). Numbers in parentheses represent standard errors. ${ }^{*} p<.05,{ }^{* *} p<.01,{ }^{* * *} p<.001$ (two-tailed). Natives are the reference category for the first and second generation immigrants, and non-religious - for religious groups. 
individuals and that this is particularly true for Muslims. ${ }^{21}$ At the same time, however, the coefficient for exposure to religious institutions is in the opposite direction, as people who attend religious services more frequently are also more engaged in politics. Furthermore, the results by action type reveal that while Christians participate in uninstitutionalized political acts less and are indistinguishable from non-religious with respect to institutionalized political acts, belonging to Islam is negatively associated with both types of political action. Hence, our analysis so far shows that immigrant generation and religion matter in shaping people's political engagement. However, statistically speaking, the estimates do not show conclusively whether participation rates among religious Muslims are significantly different from participation rates among secular individuals or whether this relationship is conditioned by immigrant generation. Furthermore, the results do not shed any light on the question of whether religion continues to be linked to participation once we take into account immigrant experiences more fully, that is, for example, when we control for democratic socialization in immigrants' country of origin and the duration of stay in one's host country. To do so, we turn to a more detailed analysis of first and second-generation immigrants.

\section{The results by immigrant generation}

To examine whether and how different aspects of religion are linked to immigrants' political participation, and to see if the strength of these relationships depend on immigrant generation, we proceed with estimating our models separately for the foreign-born and second-generation immigrants. The results of these split-sample estimations include the same control variables as in Table 1, and three additional variables designed to account for immigrant-specific experiences: political socialization measured as the level of democracy in the country of origin before immigrant's arrival, the duration of stay in one's host society, and having one foreign-born parent (as opposed to two foreign-born parents). We first report the results of our additive models, including controls, followed by models with interaction terms between religiosity and religion type. The results of these estimations are shown in Table 2 for the overall political action measure, and in Table 3 - separately for institutionalized and uninstitutionalized political acts.

Table 2 reveals that, generally speaking, belonging to a religion - be it Christianity, Islam, or other religion - is associated with less political action. Hence, in line with our expectations in Hypothesis 2, believers participate in politics less than secular individuals. This finding is consistent across immigrant generations and religious groups, although belonging to a religion other than Christianity or Islam fails to achieve statistical significance among second-generation immigrants. Interestingly, the negative coefficient of being a Muslim is larger among second-generation than first-generation immigrants, and it is considerably larger than the estimate for being a Christian.

We also find that immigrants who attend religious services more frequently are more active in politics. The positive relationship between exposure to religious institutions and political participation indicates a failure to reject Hypothesis 1 . Interestingly, the coefficient of exposure to religious institutions is almost twice as large among second-generation immigrants as among first-generation immigrants, suggesting that religious institutions may be more effective in mobilizing second-generation immigrants than foreign-born. Religiosity in itself is statistically insignificant, but the interactive models reveal that the intensity of religious beliefs and political action are linked in a less than straightforward way. Specifically, we find that while being a Muslim is associated with less engagement in politics, religiosity appears to increase political activity among second-generation Muslim immigrants. ${ }^{22}$ Taken together, our results indicate a failure to reject Hypothesis 3 that religiosity interacts with Muslim identity in shaping immigrant political engagement. Moreover, in line with Hypothesis 4, we find that this relationship is limited to second-generation immigrants, while the interaction between religiosity and being a Muslim has no observable association with political action among foreign-born.

The control variables show some interesting patterns as well. Grievances, such as feeling discriminated against and being a crime victim, have a consistent positive effect on political participation. Immigrants with extreme ideological views participate in politics more than ideologically moderate newcomers, but satisfaction with democracy has a statistically significant (negative) coefficient only among first-generation immigrants. We also find that social connectedness, education, and age are consistently linked to higher levels of political action, while other demographic variables, such as income, marital status, and gender, have no observable effect. Macro-level controls indicate that immigrants participate in politics more if they live in countries with generally more politically active populations, and that larger share of foreign-born individuals provides an additional boost for second-generation immigrants to engage politically. Moreover, foreigners socialized in more democratic countries participate in their host societies more than newcomers from less democratic regimes, while recent arrivals predictably engage in politics less than foreign-born individuals who settled in their adopted homeland long time ago. Finally, having one native-born parent facilitates political engagement among both first- and second-generation immigrants, but the effect is stronger among foreign-born.

The results reported in Table 3 reveal that the relationship between religion and political participation depends not only on immigrant generation but also on political action type. Specifically, we find that the interaction between religiosity and Islam has a positive coefficient, but this finding is limited to uninstitutionalized political engagement among second-generation immigrants. Hence, we fail to reject Hypothesis 5 that heightened religiosity among Muslims is more strongly linked to

\footnotetext{
21 Interestingly, the coefficient for belonging to a religion other than Christianity or Islam is in the opposite direction, but should not be over-interpreted considering the small size and diversity of this category.

22 Political action increases with religiosity also among second-generation immigrants who belong to other religions, but not among Christians.
} 
Table 2

Political action by immigrant generation in 18 European democracies, 2002-2010.

\begin{tabular}{|c|c|c|c|c|c|c|c|c|}
\hline \multirow{2}{*}{$\begin{array}{l}\text { Independent variable } \\
\text { Religiosity }\end{array}$} & \multicolumn{4}{|c|}{ First-generation immigrants } & \multicolumn{4}{|c|}{ Second-generation immigrants } \\
\hline & -.004 & $(.005)$ & -.004 & $(.007)$ & .000 & $(.007)$ & -.008 & $(.008)$ \\
\hline Muslim & $-.134^{* *}$ & $(.051)$ & -.112 & $(.120)$ & $-.246^{* *}$ & $(.095)$ & $-.760^{* *}$ & $(.277)$ \\
\hline Religiosity*Muslim & - & & -.003 & $(.017)$ & - & & $.078^{*}$ & $(.038)$ \\
\hline Christian & $-.143^{* * *}$ & $(.034)$ & $-.167^{* *}$ & $(.062)$ & $-.144^{* * *}$ & $(.039)$ & $-.193^{* *}$ & $(.068)$ \\
\hline Religiosity*Christian & - & & .004 & $(.010)$ & - & & .013 & $(.012)$ \\
\hline Other religion & $-.180^{*}$ & $(.078)$ & -.003 & $(.175)$ & .109 & $(.142)$ & -.555 & $(.306)$ \\
\hline Religiosity*Other religion & - & & -.029 & $(.026)$ & - & & $.121^{*}$ & $(.048)$ \\
\hline Religious services attendance & $.027^{* *}$ & $(.010)$ & $.027^{*}$ & $(.010)$ & $.057^{* * * *}$ & $(.014)$ & $.055^{* * *}$ & $(.014)$ \\
\hline Citizen & .050 & $(.032)$ & .050 & $(.032)$ & $.223^{* *}$ & $(.073)$ & $.219^{* *}$ & $(.073)$ \\
\hline One foreign-born parent & $.141^{* *}$ & $(.045)$ & $.141^{* *}$ & $(.045)$ & $.105^{* *}$ & $(.038)$ & $.104^{* *}$ & $(.038)$ \\
\hline Social connectedness & $.072^{* * *}$ & $(.009)$ & $.072^{* * *}$ & $(.009)$ & $.087^{* * *}$ & $(.011)$ & $.087^{* * *}$ & $(.011)$ \\
\hline Satisfaction with democracy & $-.028^{* * *}$ & $(.006)$ & $-.028^{* * * *}$ & $(.006)$ & -.004 & $(.007)$ & -.003 & $(.007)$ \\
\hline Crime victim & $.315^{* * *}$ & $(.032)$ & $.314^{* * *}$ & $(.032)$ & $.199^{* * *}$ & $(.036)$ & $.200^{* * *}$ & $(.036)$ \\
\hline Discriminated against & $.219^{* * *}$ & $(.038)$ & $.219^{* * *}$ & $(.038)$ & $.468^{* * *}$ & $(.055)$ & $.473^{* * *}$ & $(.055)$ \\
\hline Ideological extremity & $.068^{* * *}$ & $(.009)$ & $.068^{* * *}$ & $(.009)$ & $.111^{* * *}$ & $(.011)$ & $.110^{* * *}$ & $(.011)$ \\
\hline Male & .002 & $(.027)$ & .002 & $(.027)$ & .040 & $(.031)$ & .038 & $(.031)$ \\
\hline Age & $.031^{* * *}$ & $(.005)$ & $.031^{* * *}$ & $(.005)$ & $.042^{* * *}$ & $(.005)$ & $.042^{* * *}$ & $(.005)$ \\
\hline Age squared & $-.000^{* * *}$ & $(.000)$ & $-.000^{* * *}$ & $(.000)$ & $-.000^{* * *}$ & $(.000)$ & $-.000^{* * *}$ & $(.000)$ \\
\hline Married & $-.063^{*}$ & $(.029)$ & $-.064^{*}$ & $(.029)$ & -.015 & $(.035)$ & -.015 & $(.035)$ \\
\hline Education & $.053^{* * *}$ & $(.003)$ & $.053^{* * *}$ & $(.003)$ & $.069^{* * *}$ & $(.004)$ & $.069^{* * *}$ & $(.004)$ \\
\hline Unemployed & $-.113^{*}$ & $(.050)$ & $-.113^{*}$ & $(.050)$ & -.003 & $(.066)$ & -.008 & $(.066)$ \\
\hline Income & .002 & $(.017)$ & .002 & $(.017)$ & .008 & $(.021)$ & .008 & $(.021)$ \\
\hline GDP per capita (in 1,000 of $\$$ 's) & .002 & $(.004)$ & .002 & $(.004)$ & -.005 & $(.005)$ & -.005 & $(.005)$ \\
\hline Economic growth (\%) & -.002 & $(.007)$ & -.002 & $(.007)$ & .016 & $(.009)$ & .016 & $(.009)$ \\
\hline Government effectiveness & .122 & $(.069)$ & .121 & $(.069)$ & -.099 & $(.079)$ & -.096 & $(.078)$ \\
\hline$\%$ foreign-born & -.002 & $(.005)$ & -.002 & $(.005)$ & $.017^{* *}$ & $(.006)$ & $.017^{* *}$ & $(.006)$ \\
\hline Average political participation & $.515^{* * *}$ & $(.111)$ & $.513^{* * *}$ & $(.111)$ & $.806^{* * *}$ & $(.133)$ & $.807^{* * *}$ & $(.132)$ \\
\hline Democracy in country of origin & $.005^{*}$ & $(.002)$ & $.005^{*}$ & $(.002)$ & - & & - & \\
\hline Recent arrival & $-.129^{* * *}$ & $(.015)$ & $-.129^{* * * *}$ & $(.015)$ & - & & - & \\
\hline Contant & $-1.359^{* * *}$ & $(.187)$ & $-1.362^{* * *}$ & $(.187)$ & $-2.292^{* * *}$ & $(.206)$ & $-2.286^{* * *}$ & $(.205)$ \\
\hline \multicolumn{9}{|l|}{ Variance components } \\
\hline Country level & .006 & $(.004)$ & .006 & $(.004)$ & .008 & $(.004)$ & .007 & $(.004)$ \\
\hline Individual level & 1.178 & $(.020)$ & 1.178 & $(.020)$ & 1.461 & $(.026)$ & 1.458 & $(.026)$ \\
\hline Number of observations & \multicolumn{2}{|c|}{6,961} & \multicolumn{2}{|c|}{6,961} & \multicolumn{2}{|c|}{6,269} & \multicolumn{2}{|c|}{6,269} \\
\hline Number of groups & \multicolumn{2}{|c|}{18} & \multicolumn{2}{|c|}{18} & \multicolumn{2}{|c|}{18} & \multicolumn{2}{|c|}{18} \\
\hline Wald $X^{2}$ (df) & \multicolumn{2}{|c|}{$1085.6(26)^{* * *}$} & \multicolumn{2}{|c|}{$1088.3(29)^{* * *}$} & \multicolumn{2}{|c|}{$946.9(24)^{* * *}$} & \multicolumn{2}{|c|}{$960.9(27)^{* * * *}$} \\
\hline
\end{tabular}

Note: The results are multi-level (random intercept) linear regression estimates (using STATA's xtmixed command). Numbers in parentheses represent standard errors. ${ }^{*} p<.05,{ }^{* *} p<.01,{ }^{* * *} p<.001$ (two-tailed). Non-religious are the reference category for religious groups; the reference category for 'one foreign-born parent' is having both foreign-born parents.

uninstitutionalized than institutionalized political engagement. In contrast, while attendance of religious services is associated with more political engagement among all respondents, this relationship among immigrants is limited to institutionalized channels. Taken together, the results suggest that while religious institutions help mobilize immigrants for institutionalized political engagement, religiosity appears to motivate second-generation Muslims to engage in uninstitutionalized political acts. ${ }^{23}$

How much do religion and religiosity matter for immigrant political behavior in substantive terms? Using the results from the interaction models for second-generation immigrants, Fig. 3 reports the predicted values of uninstitutionalized political participation among second-generation Muslim, Christian, and secular individuals. The white bars indicate the levels of political engagement among respondents with low levels of religiosity and grey bars - among individuals with high levels of religiosity (calculated as $\pm 2 \mathrm{SD}$ from the mean of one's religious group among second-generation immigrants), while the vertical bars report the $95 \%$ confidence intervals.

The results reveal that religiosity is indeed strongly linked to uninstitutionalized political action among second-generation Muslim immigrants. Political engagement increases from .441 to .990 when we compare Muslims with low and high levels of religiosity (a difference of .549), and this difference is statistically significant. In contrast, the levels of participation in politics are barely distinguishable among Christians when we move from low to high levels of religiosity (.726 vs. .749). We also find that secular individuals are more politically engaged (with a score of .852) than Christians of any religiosity level and slightly less active than highly religious Muslims (.990), but these differences are statistically insignificant. At the same time, however,

\footnotetext{
${ }^{23}$ We performed a number of analyses to test the robustness of our findings. Specifically, we re-estimated our models using (1) life satisfaction that was previously employed by Dalton and his colleagues as an alternative measure of grievances (Dalton et al., 2010; Dalton and van Sickle, 2005); (2) respondents' internal efficacy and proficiency in official host country's language; and (3) countries' openness towards immigrants in a form of citizenship policy regimes (Howard, 2009), migrant integration policies (MIPEX, Niessen et al., 2007), and anti-immigrant attitudes among natives. The results (available from the authors upon request) revealed that our findings do not change as a consequence of controlling for these variables and our inferences remain the same.
} 
Table 3

Institutionalized and uninstitutionalized political action by immigrant generation in 18 European democracies, $2002-2010$.

\begin{tabular}{|c|c|c|c|c|c|c|c|c|}
\hline \multirow{3}{*}{$\begin{array}{l}\text { Independent variables } \\
\text { Religiosity }\end{array}$} & \multicolumn{4}{|c|}{ Institutionalized political action } & \multicolumn{4}{|c|}{ Uninstitutionalized political action } \\
\hline & \multicolumn{2}{|c|}{$\begin{array}{l}\text { First-generation } \\
\text { immigrants }\end{array}$} & \multicolumn{2}{|c|}{$\begin{array}{l}\text { Second-generation } \\
\text { immigrants }\end{array}$} & \multicolumn{2}{|c|}{$\begin{array}{l}\text { First-generation } \\
\text { immigrants }\end{array}$} & \multicolumn{2}{|c|}{$\begin{array}{l}\text { Second-generation } \\
\text { immigrants }\end{array}$} \\
\hline & $\begin{array}{l}-.001 \\
(.003)\end{array}$ & $\begin{array}{l}-.002 \\
(.004)\end{array}$ & $\begin{array}{l}-.003 \\
(.004)\end{array}$ & $\begin{array}{l}-.008 \\
(.005)\end{array}$ & $\begin{array}{l}-.003 \\
(.004)\end{array}$ & $\begin{array}{l}-.003 \\
(.005)\end{array}$ & $\begin{array}{l}.003 \\
(.004)\end{array}$ & $\begin{array}{l}-.001 \\
(.005)\end{array}$ \\
\hline Muslim & $\begin{array}{l}-.043 \\
(.028)\end{array}$ & $\begin{array}{l}-.029 \\
(.066)\end{array}$ & $\begin{array}{l}-.076 \\
(.055)\end{array}$ & $\begin{array}{l}-.155 \\
(.161)\end{array}$ & $\begin{array}{l}-.090^{*} \\
(.035)\end{array}$ & $\begin{array}{l}-.082 \\
(.083)\end{array}$ & $\begin{array}{l}-.150^{*} \\
(.064)\end{array}$ & $\begin{array}{l}-.566^{* *} \\
(.186)\end{array}$ \\
\hline Religiosity* Muslim & - & $\begin{array}{l}-.002 \\
(.009)\end{array}$ & - & $\begin{array}{l}.015 \\
(.022)\end{array}$ & - & $\begin{array}{l}-.001 \\
(.012)\end{array}$ & - & $\begin{array}{l}.061^{*} \\
(.025)\end{array}$ \\
\hline Christian & $\begin{array}{l}-.051^{* *} \\
(.018)\end{array}$ & $\begin{array}{l}-.078^{*} \\
(.034)\end{array}$ & $\begin{array}{l}-.010 \\
(.022)\end{array}$ & $\begin{array}{l}-.053 \\
(.039)\end{array}$ & $\begin{array}{l}-.092^{* * *} \\
(.023)\end{array}$ & $\begin{array}{l}-.092^{*} \\
(.043)\end{array}$ & $\begin{array}{l}-.122^{* * *} \\
(.026)\end{array}$ & $\begin{array}{l}-.131^{* *} \\
(.045)\end{array}$ \\
\hline Religiosity* Christian & - & $\begin{array}{l}.004 \\
(.006)\end{array}$ & - & $\begin{array}{l}.010 \\
(.007)\end{array}$ & - & $\begin{array}{l}-.000 \\
(.007)\end{array}$ & - & $\begin{array}{l}.003 \\
(.008)\end{array}$ \\
\hline Other religion & $\begin{array}{l}-.003 \\
(.043)\end{array}$ & $\begin{array}{l}.175 \\
(.095)\end{array}$ & $\begin{array}{l}.070 \\
(.083)\end{array}$ & $\begin{array}{l}-.339 \\
(.179)\end{array}$ & $\begin{array}{l}-.177^{* * *} \\
(.054)\end{array}$ & $\begin{array}{l}-.173 \\
(.120)\end{array}$ & $\begin{array}{l}.045 \\
(.096)\end{array}$ & $\begin{array}{l}-.217 \\
(.205)\end{array}$ \\
\hline Religiosity* Other religion & - & $\begin{array}{l}-.029^{*} \\
(.014)\end{array}$ & - & $\begin{array}{l}.075^{* *} \\
(.028)\end{array}$ & - & $\begin{array}{l}-.001 \\
(.018)\end{array}$ & - & $\begin{array}{l}.048 \\
(.032)\end{array}$ \\
\hline Religious services attendance & $\begin{array}{l}.024^{* * *} \\
(.006)\end{array}$ & $\begin{array}{l}.024^{* * * *} \\
(.006)\end{array}$ & $\begin{array}{l}.043^{* * *} \\
(.008)\end{array}$ & $\begin{array}{l}.041^{* * *} \\
(.008)\end{array}$ & $\begin{array}{l}.004 \\
(.007)\end{array}$ & $\begin{array}{l}.004 \\
(.007)\end{array}$ & $\begin{array}{l}.015 \\
(.009)\end{array}$ & $\begin{array}{l}.014 \\
(.009)\end{array}$ \\
\hline Individual-level controls & Yes & Yes & Yes & Yes & Yes & Yes & Yes & Yes \\
\hline Country-level controls & Yes & Yes & Yes & Yes & Yes & Yes & Yes & Yes \\
\hline Constant & $\begin{array}{l}-.629^{* * *} \\
(.100)\end{array}$ & $\begin{array}{l}-.631^{* * *} \\
(.100)\end{array}$ & $\begin{array}{l}-1.446^{* * * *} \\
(.105)\end{array}$ & $\begin{array}{l}-1.445^{* * *} \\
(.105)\end{array}$ & $\begin{array}{l}-.720^{* * * *} \\
(.125)\end{array}$ & $\begin{array}{l}-.720^{* * *} \\
(.125)\end{array}$ & $\begin{array}{l}-.848^{* * *} \\
(.140)\end{array}$ & $\begin{array}{l}-.846^{* * *} \\
(.139)\end{array}$ \\
\hline \multicolumn{9}{|l|}{ Variance components } \\
\hline Country level & $\begin{array}{l}.001 \\
(.001)\end{array}$ & $\begin{array}{l}.001 \\
(.001)\end{array}$ & $\begin{array}{l}.000 \\
(.000)\end{array}$ & $\begin{array}{l}.000 \\
(.000)\end{array}$ & $\begin{array}{l}.002 \\
(.001)\end{array}$ & $\begin{array}{l}.002 \\
(.001)\end{array}$ & $\begin{array}{l}.004 \\
(.002)\end{array}$ & $\begin{array}{l}.004 \\
(.002)\end{array}$ \\
\hline Individual level & $\begin{array}{l}.353 \\
(.006)\end{array}$ & $\begin{array}{l}.353 \\
(.006)\end{array}$ & $\begin{array}{l}.499 \\
(.009)\end{array}$ & $\begin{array}{l}.498 \\
(.009)\end{array}$ & $\begin{array}{l}.559 \\
(.009)\end{array}$ & $\begin{array}{l}.559 \\
(.009)\end{array}$ & $\begin{array}{l}.657 \\
(.012)\end{array}$ & $\begin{array}{l}.657 \\
(.012)\end{array}$ \\
\hline Number of observations & \multicolumn{2}{|c|}{6989} & \multicolumn{2}{|c|}{6303} & \multicolumn{2}{|c|}{6976} & \multicolumn{2}{|c|}{6287} \\
\hline Number of groups & \multicolumn{2}{|c|}{18} & \multicolumn{2}{|c|}{18} & \multicolumn{2}{|c|}{18} & \multicolumn{2}{|c|}{18} \\
\hline Wald $X^{2}(\mathrm{df})$ & $\begin{array}{l}515.7 \\
(26)^{* * * *}\end{array}$ & $\begin{array}{l}522.2 \\
(29)^{* * * *}\end{array}$ & $\begin{array}{l}677.4 \\
(24)^{* * * *}\end{array}$ & $\begin{array}{l}686.9 \\
(27)^{* * *}\end{array}$ & $\begin{array}{l}1034.6 \\
(26)^{* * *}\end{array}$ & $\begin{array}{l}1034.4 \\
(29)^{* * *}\end{array}$ & $\begin{array}{l}851.3 \\
(24)^{* * * *}\end{array}$ & $\begin{array}{l}861.0 \\
(27)^{* * *}\end{array}$ \\
\hline
\end{tabular}

Note: The results are multi-level (random intercept) linear regression estimates (using STATA's xtmixed command). Numbers in parentheses represent standard errors. ${ }^{*} p<.05,{ }^{* *} p<.01,{ }^{* * *} p<.001$ (two-tailed). Non-religious are the reference category for religious groups.



Fig. 3. Predicted effects of religion and religiosity on uninstitutionalized political action among second-generation immigrants in 18 West European democracies.

secular individuals clearly exhibit more political activism than Muslims with low levels of religiosity. Taken together, the results reveal that political engagement among second-generation Muslims increases with religiosity, but heightened religiosity merely brings their political activism to the same level as the one observed in the secular public.

To assess the substantive and statistical significance of our key variables of interest in more detail, Fig. 4 reports how the magnitude of the marginal effect of religiosity (with 95\% confidence intervals) on uninstitutionalized political action changes when we compare Muslims and non-Muslims among second-generation immigrants. Consistent with our expectations, the marginal effect of religiosity among Muslims is positive and statistically distinguishable from 0 , while the marginal effect for non-Muslims is both statistically and substantively insignificant. Specifically, we find that one unit change in religiosity is 


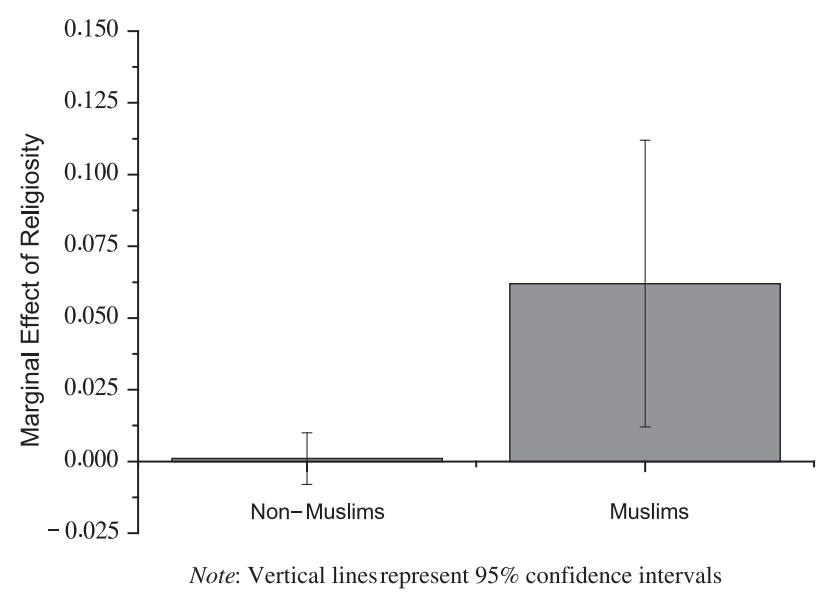

Fig. 4. Marginal effect of religiosity on uninstitutionalized political action among second-generation muslim and non-muslim immigrants in 18 Western democracies.

associated with a .0603 increase in engagement in uninstitutionalized political action among Muslims. This means that moving from the minimum to the maximum value of religiosity (on a scale from 0 to 10) is associated with a .603 increase in the score of uninstitutionalized political action (that is, a change from .289 to .892 on a scale from 0 to 3 ). ${ }^{24}$

The magnitude of this substantive relationship between religion and political participation among second-generation Muslim immigrants (.603) is similar or even higher than the effects of some traditional predictors of political participation, such as age and education. For example, if we compare the scores of uninstitutionalized political action of respondents aged 18 and 45 (that is, the age when political activism appears to peak), the difference is only .112 (.743 vs. .855). Receiving 12 years of full-time education in comparison to no education at all increases the score of uninstitutionalized political action by .492 points (.328 vs. .820 ), while 16 years of full-time education (an equivalent of a BA degree in many countries) in comparison to no education is associated with a .656 point increase in uninstitutionalized political acts (.330 vs. .984). Taken together, the results indicate that religiosity is strongly linked to uninstitutionalized political mobilization among secondgeneration Muslim immigrants in Western Europe.

\section{Conclusion}

The relationships between migration, religion, and political action form a hot triangle in contemporary political debates in many European countries. By providing a systematic analysis on how these factors are related, our study speaks to an ongoing debate over the future of Islam in contemporary democracies. As Muslims have increased their presence in Europe, concerns about their integration are at the core of political debates and policy agendas in many western societies. The key concerns revolve around whether immigrants - especially those from culturally distinct societies - should and can integrate into their new homeland, whether their religious beliefs are compatible with the key principles of democratic governance, and what consequences integration efforts (or lack of thereof) might have for the prospects of peaceful coexistence and constructive dialogue among different religions as well as between believers and the secular public.

To respond to these debates, we analyze whether immigrants' engagement in political action is linked to their religious affiliation, and the extent to which these relationships are conditioned by immigrant generation, religiosity, and the nature of political action. It is a key finding of this paper that among Muslim immigrants not only is religiosity stronger among second-generation than foreign-born, but also that the relationship between religiosity and uninstitutionalized political action is more pronounced in the second-generation. We attribute this finding to different attitudes towards host society in the two immigrant generations. Specifically, first-generation immigrants self-select into the process of migration, choosing countries where they believe they will have a better life than in their country of origin. As a consequence, they are more positively predisposed towards their host societies than second-generation immigrants who were born into their status instead of becoming immigrants by choice. Being born in their host society - yet not feeling fully at home due to the way society at large perceives them - second-generation immigrants are more inclined to rediscover and embrace the roots of their identity - including religion, cultural traditions and practices. This turn to "reactive identity" - often taken as a way of dealing with discrimination and injustice ${ }^{25}$ - then motivates political engagement among Muslim immigrants in an effort to create and secure conditions where they can properly practice their beliefs.

\footnotetext{
${ }^{24}$ We hold other variables at their means and dichotomous variables - at their medians.

25 The ESS data indicate that while $42 \%$ of second-generation Muslim immigrants reported feeling discriminated against in their host country, only $32 \%$ of foreign-born Muslims expressed such a view. Similarly, second-generation Muslim immigrants are significantly less satisfied with the way democracy works in their host country than first-generation Muslim immigrants: the mean scores are 5.89 and 6.60, respectively. Hence, socio-political grievances are higher among second-generation Muslims than foreign-born Muslims.
} 
Although political activism among second-generation Muslim immigrants increases with the intensity of their religious convictions, it is worth noting that heightened religiosity merely brings their political activism to the same level as the one observed in the secular public. In other words, highly religious Muslims are indistinguishable from non-believers, while the least devout Muslims participate significantly less than non-believers. In comparison, there is little difference in the levels of political participation between Christians of any religiosity level and secular individuals. Hence, religion - be it Christian or Muslim - in itself does not drive political activity. But belonging to a religion that is distinct and less accepted by the majority public, such as Islam, and holding intense religious beliefs can encourage believers to participate in politics as much as the secular public does. This is because religion has aspects which could lead the individual away from political strife and conflict, as religious beliefs and upholding praying routines take precedence over worldly affairs and considerations. At the same time religion has a motivational component, which in combination with particular conditions may lead to increased political activity. Specifically, religion shapes people's views towards a wide range of issues - such as abortion, gay marriage, or alcohol prohibition - that may stimulate political action. Moreover, the need to take time off for prayers, build places of worship, or acquire permission to wear the veil in public places may directly raise political involvement among more devout believers. In sum, religion is a complex phenomenon and its relationship to politics is not always easy to predict.

Several other empirical findings are also of interest. Citizenship is positively related to participation, as are grievances, such as feeling discriminated against and being a crime victim. These findings are interesting in light of the classic studies of political action (Barnes et al., 1979) and more recent research (Dalton et al., 2010) which downplay the role of grievances and emphasize the role of modernization and development in societies. Furthermore, we find that if an immigrant comes from a more democratic country, political activity in the new country is higher than for arrivals from less democratic countries. Our results also show that immigrants who have lived in the new country for a short period of time are less involved in political participation than those who have stayed for a longer period, suggesting that political integration takes place not only across immigrant generations but also with exposure to a host society over one's life-time among the foreign-born. These findings point to interesting dynamics and interactions of the political life courses of immigrants with macro characteristics of countries that the migrants left behind as well as with characteristics of the countries of arrival.

Overall, our paper shows that religion is strongly linked to immigrants' political engagement, especially when immigrant generation is taken to account. Future research should further examine the political consequences of immigrant identity by taking into account other aspects, such as language, ethnicity and race. Existing research shows that, like religion, ethnicity can both motivate and inhibit political participation of minorities (Sandovici and Listhaug, 2010), but little is known whether this is equally true for immigrants as it is for native minority populations in contemporary democracies. ${ }^{26}$ Moreover, research would also benefit from more detailed analyses whether divisions within Islam (e.g., between Sunnis and Shiites) leave a mark on political behavior of Muslim immigrants in Western societies as they do in other parts of the world. In short, future studies on these issues would enable us to develop a more comprehensive understanding on how various aspects of immigrant identity contribute to their political activism in contemporary democracies.

Finally, it is worth noting that the political activities we investigate in this article are non-violent in kind. The peaceful forms of protest which are included in the index for political action - participating in lawful demonstrations, boycotts, and signing of petitions - are part of the democratic repertoire in democracies and should add to the democratic training and socialization of immigrants as well as of other groups in the polity. Participation in these forms of political action should lead to political integration rather than to escalating conflicts, and may ultimately prevent more violent manifestations of immigrants' grievances. Further research would benefit from more detailed analyses of specific issues that trigger political action and whether political movements recruit participants across the divide between immigrants and natives. In the meantime, we conclude that in light of growing diversity of European societies, understanding the consequences of religion in shaping immigrant political behavior is an important step towards a constructive inter-faith dialogue, democratic pluralism, and continued stability of contemporary democracies.

\section{Acknowledgments}

Aida Just would like to thank the Turkish Academy of Sciences (TÜBA) for the GEBIP award that supported her work on this project. We also acknowledge the advice and comments from Arild Blekesaune, Joakim Dalen, Henning Finseraas, and Kristen Ringdal.

\section{Appendix A. Measures and coding}

Political action: Additive index based on the following survey items: "There are different ways of trying to improve things in [country] or help prevent things from going wrong. During the last 12 months, have you done any of the following? (1) Contacted a politician, government or local government official, (2) worked in apolitical party or action group, (3) worked in another organization or association? (4) signed a petition? (5) taken part in a lawful public demonstration, (6) boycotted certain products?" The measure ranges from 0 to 6 , with higher values indicating more politically active respondents.

\footnotetext{
${ }^{26}$ Sandovici and Listhaug's (2010) study is based on both immigrant and native populations, but it does not systematically analyze whether the patterns of political engagement among immigrants are considerably different from the ones of native minorities.
} 
Institutionalized political action: Additive index based on the following survey items: "There are different ways of trying to improve things in [country] or help prevent things from going wrong. During the last 12 months, have you done any of the following? (1) Contacted a politician, government or local government official, (2) worked in apolitical party or action group, (3) worked in another organisation or association?" The measure ranges from 0 to 3 , with higher values indicating more active respondents.

Uninstitutionalized political action: Additive index based on the following survey items: "There are different ways of trying to improve things in [country] or help prevent things from going wrong. During the last 12 months, have you done any of the following? (1) signed a petition? (2) taken part in a lawful public demonstration, (3) boycotted certain products? The measure ranges from 0 to 3 , with higher values indicating more politically active respondents.

First-generation immigrant: "Were you born in this country?" 0 'yes', 1 'no'. Foreign-born with both native-born parents were excluded from the analyses.

Second-generation immigrant: Based on three survey items: "Were you born in [country]?", "Was your father born in [country]?", and "Was your mother born in [country]?" Coded 1 if a response to the first question was 'yes' and a response to the second and/or third question was 'no'; 0 - otherwise.

Religion: Based on two survey items: "Do you consider yourself as belonging to any particular religion or denomination?" If so, "Which one?" Using response categories to this survey question, we created dichotomous variables for Muslims, Christians (the latter includes Roman Catholics, Protestants, Eastern Orthodox, or other Christian denomination), and other religions (Jews, Eastern religions, and other non-Christian religions).

Religiosity: "Regardless of whether you belong to a particular religion, how religious would you say you are?" The variable ranges from 0 (not at all religious), to 10 (very religious).

Religious services attendance: "Apart from special occasions such as weddings and funerals, about how often do you attend religious services nowadays?" The variable ranges from 0 (never), to 6 (every day).

Democracy in country of origin: Based on survey questions: "Were you born in [country]?" If a respondent said "no", then the follow up question was "In which country were you born?" and "How long ago did you first come to live in [country]?" Information about immigrant country of origin and the recency of immigrant arrival were then matched up with the polity scores from the Polity IV data set http://www.cidcm.umd.edu/polity/. Since recency of immigrant arrival is a categorical variable that captures only approximate number of years in host country, we calculated variable values in the following way. If a survey was conducted in 2002, then those who arrived more than 20 years ago were assigned the average value of the 19721981 polity score in their country of origin, those who arrived 11-20 years ago the 1982-1991 score, those who arrived 610 years ago the 1992-1996 score, those who arrived 1-5 years ago the 1997-2001 score, and those who arrived within the last year the 2002 score. We then calculated values separately for respondents interviewed in 2003, 2004, 2005, 2006, 2007, 2008,2009 , and 2010. This generated a variable that ranges from 0 'least democratic regime' to 20 'most democratic regime' (recoded from the original polity measure that ranges from -10 to 10 ).

Recent arrival: "How long ago did you first come to live in [country]?" 5 'within last year', 4 '1-5 years ago', 3 '6-10 years ago', 2 '11-20 years ago', 1 'more than 20 years ago'.

Citizenship status: "Are you a citizen of [country]?" 1 'yes', 0 'no'.

One foreign-born parent: 1 'One Foreign-born Parent', 0 'Both Foreign-born Parents.'

Age: Number of years (calculated by subtracting respondent's year of birth from the year of interview).

Male: 1 'male', 0 'female'.

Married: 1 'married', 0 'otherwise'.

Education: Years of full-time education completed.

Income: "Which of the descriptions on this card comes closest to how you feel about your household's income nowadays?" 0 'very difficult on present income', 1 'difficult on present income', 2 'coping on present income', 3 'living comfortably on present income'.

Unemployed: Based on two survey questions: "Which of these descriptions applies to what you have been doing for the last 7 days? (1) unemployed and actively looking for a job; (2) unemployed, wanting a job but not actively looking for a job. This is a dichotomous variable, coded as 1 if a respondent gave a positive answer to at least one of these two questions, 0 otherwise.

Social connectedness: "How often do you meet socially with friends, relatives or work colleagues?" 1 'never', 2 'less than once a month', 3 'once a month', 4 'several times a month', 5 'once a week', 6 'several times a week', 7 'every day'.

Discriminated against: "Would you describe yourself as being a member of a group that is discriminated against in this country?" 1 'yes', 0 'no'.

Crime victim: "Have you or a member of your household been the victim of a burglary or assault in the last 5 years?" 1 'yes', 0 'no'.

Satisfaction with democracy: "And on the whole, how satisfied are you with the way democracy works in [country]?" 0 'extremely dissatisfied', 10 'extremely satisfied'.

Ideological extremity: Based on survey question "In politics people sometimes talk of "left" and "right". Using this card, where would you place yourself on this scale, where 0 means the left and 10 means the right?" Using responses to this item we first computed country median left-right position (in each ESS round), and then employed it to calculate absolute distance between country median and respondent's position. 
GDP per capita: Based on purchasing power parity (PPP) in constant 2005 international dollars (in 1000's) on the ESS survey year. Source: World Bank, World Development Indicators, On-line edition. Washington DC: World Bank (2012).

Economic growth: Annual percentage growth rate of GDP per capita on the ESS survey year. Source: World Bank, World Development Indicators, On-line edition. Washington DC: World Bank (2012).

Government effectiveness: Composite measure of perceptions of various agents (including mass public, firms, non-governmental organizations, commercial business information providers, and public sector organizations) about the quality of public services, the quality of the civil service and the degree of its independence from political pressures, the quality of policy formulation and implementation, and the credibility of the government's commitment to such policies. Source: World Bank, Worldwide Governance Indicators. http://info.worldbank.org/governance/wgi/resources.htm.

Foreign population size: \% of foreign-born population; calculated using the ESS1-4 data for each country in each ESS round.

Average political participation: A mean value of political participation (political action, institutionalized, or uninstitutionalized political action, depending on the model) calculated using all respondents in each country (in each ESS round).

\section{References}

Aleksynska, M., 2011. Civic participation of immigrants in Europe: assimilation, origin, and destination country effects. The European Journal of Political Economy 27, 566-585.

Alesina, A., Giuliano, P., 2011. Family ties and political participation. Journal of the European Economic Association 9, $817-839$.

Almond, G.A., Verba, S., 1963. The Civic Culture. Little, Brown and Company, Boston, MA.

Barnes, S., Kaase, M., Allerbeck, K., Farah, B., Heunks, F., Inglehart, R., Jennings, M.K., Klingemann, H-D., Marsh, A., Rosenmayr, L., 1979. Political Action: Mass Participation in Five Western Democracies. Sage Publications, Beverly Hills, CA.

Bass, L.E., Casper, L.M., 2001. Impacting the political landscape: who registers and votes among naturalized Americans? Political Behavior 23, $103-130$.

Bateson, R., 2012. Crime victimization and political participation. American Political Science Review 106, 570-587.

Bellin, E., 2008. Faith in politics: new trends in the study of religion and politics. World Politics 60, $315-347$.

Benabou, R., Tirole, J., 2006. Belief in a just world and redistributive politics. Quarterly Journal of Economics 121, 699-746.

Black, J.H., 1987. The practice of politics in two settings: political transferability among recent immigrants to Canada. Canadian Journal of Political Science $20,731-753$

Black, J.H., Niemi, R., Powell, B.G., 1987. Age and resistance to political learning in a new environment: the case of Canadian immigrants. Comparative Politics 20, 73-84.

Bloemraad, I., 2006. Becoming a citizen in the United States and Canada: structured mobilization and immigrant political incorporation. Social Forces 85, $667-695$.

Brady, H.E., Verba, S., Schlozman, K.L., 1995. Beyond SES: a resource model of political participation. American Political Science review 89, $271-294$.

Branscombe, N.R., Schmitt, M.T., Harvey, R.D., 1999. Perceiving pervasive discrimination among African-Americans: implications for group identification and well-being. Journal of Personality and Social Psychology 77, 135-149.

Bueker, C.S., 2005. Political incorporation among immigrants from ten areas of origin: the persistence of source country effects. International Migration Review 39, 103-140.

Buijs, F.J., Rath, J., 2002. Muslims in Europe: the state of research. Russell Sage Foundation, New York.

Buijs, F.J., Rath, J., 2006. Muslims in Europe: The State of Research. IMISCOE Working Paper. <http://www.imiscoe.org/workingpapers/documents/ muslims_in_europe>.

Castles, S., Miller, M.J., 2009. The Age of Migration: International Population Movements in the Modern World, fourth ed. Palgrave Macmillan.

Cesari, J., 2004. When Islam and Democracy Meet: Muslims in Europe and the United States. Palgrave Macmillan, New York, NY.

Connor, P., 2010. Contexts of immigrant receptivity and immigrant religious outcomes: the case of Muslims in Western Europe. Ethnic and Racial Studies 33 $376-403$.

Converse, P.E., 1974. Some priority variables in comparative electoral research. In: Rose, R. (Ed.), Electoral behavior: a comparative handbook. Free Press, New York, pp. 727-745.

Craig, S.C., Maggiotto, M.A., 1981. Political discontent and political action. Journal of Politics 43, 514-522.

Dalton, R.J., 2006. Citizen Politics: Public Opinion and Political Parties in Advanced Industrial Democracies, fourth ed. CQ Press, Washington, DC.

Dalton, R.J., van Sickle, A., 2005. The Resource, Structural and Cultural Bases of Protest. Center for the Study of Democracy. Paper 05-11. <http:// repositories.cdlib.org/csd/05-11>.

Dalton, R.J., van Sickle, A., Weldon, S., 2010. The individual-institutional nexus of protest behavior. British Journal of Political Science 40, 51-73.

Dancygier, R., Saunders, E.N., 2006. A new electorate? Comparing preferences and partisanship between immigrants and natives. American Journal of Political Science 50, 962-981.

de Rooij, E.A., 2012. Patterns of immigrant political participation: explaining differences in types of political participation between immigrants and the majority population in Western Europe. European Sociological Review 28, 455-481.

DeSipio, L., 1996. Making citizens or good citizens? Naturalization as a predictor of organizational and electoral behavior among Latino immigrants. Hispanic Journal of Behavioral Sciences 18, 194-213.

Diehl, C., Koenig, M., 2009. Religiosität türkischer migranten im generationenverlauf: ein befund und einige erklärungsversuche. Zeitschrift für Soziologie $38,300-319$.

Djupe, P.A., Grant, J.T., 2001. Religious institutions and political participation in America. Journal for the Scientific Study of Religion 40, 303-314.

Ebaugh, H.R., Chafetz, J.S., 2000. Religion and the New Immigrants. Continuities and Adaptations in Immigrant Congregations. AltaMira, Walnut Creek, CA.

Eggert, N., Giugni, M., 2011. The impact of religion on the political participation of migrants. In: Morales, L., Giugni, M. (Eds.), Social Capital, Political Participation and Migration in Europe - Making Multicultural Democracy Work? Palgrave McMillan, pp. 219-237.

Eisinger, P.K., 1973. The conditions of protest behavior in American cities. American Political Science Review 67, 11-28.

Fetzer, J.S., Soper, C.J., 2005. Muslims and the state in Britain, France, and Germany. Cambridge University Press, Cambridge.

Finkel, S.E., 1985. Reciprocal effects of participation and political efficacy: a panel analysis. American Journal of Political Science 29 , $891-913$.

Fleischmann, F., Phalet, K., Klein, O., 2011. Religious identification and politicization in the face of discrimination: support for political Islam and political action among the Turkish and Moroccan second generation in Europe. British Journal of Social Psychology 50, 628-648.

Fleischmann, F., Phalet, K., 2012. Integration and religiosity among the Turkish second generation in Europe: a comparative analysis across four capital cities. Ethnic and Racial Studies 35, 320-341.

Foley, M.W., Hoge, D.R., 2007. Religion and the New Immigrants: How Faith Communities form Our Newest Citizens. Oxford University Press, Oxford.

Foner, N., Alba, R., 2008. Immigrant religion in the US and Western Europe: bridge or barrier to inclusion? International Migration Review 42, 577-592.

Gamson, W.A., 1968. Power and Discontent. Dorsey Press, Homewood, IL.

Giugni, M., 2007. Useless protest? A time-series analysis of the policy outcomes of ecology, antinuclear, and peace movements in the United States, 19771995. Mobilization: An. International Quarterly 12, 53-77.

Grzymala-Busse, A., 2012. Why comparative politics should take religion (more) seriously. Annual Review of Political Science 15, 421-442. 
Gurr, T.R., 1970. Why Men Rebel. Princeton University Press, Princeton, NJ.

Haddad, Y.Y., 2007. The post-9/11 hijab as icon. Sociology of Religion 68, 253-267.

Hansen, S.B., 1997. Talking about politics: gender and contextual effects on political proselytizing. Journal of Politics 59, $73-103$.

Harris, F.C., 1994. Something within: religion as a mobilizer of African-American political activism. Journal of Politics 56, $42-68$.

Hirschman, C., 2004. The role of religion in the origins and adaptation of immigrant groups in the United States. International Migration Review 38, 12061233.

Hopkins, N., Kahani-Hopkins, V., 2004. Identity construction and British Muslims' political activity: beyond rational actor theory. British Journal of Social Psychology 43, 339-356.

Howard, M.M., 2009. The Politics of Citizenship in Europe. Cambridge University Press, Cambridge.

Inglehart, R., Welzel, C., 2005. Modernization, Cultural Change and Democracy: The Human Development Sequence. Cambridge University Press, New York, NY.

Jamal, A., 2005. The political participation and engagement of Muslim Americans: mosque involvement and group consciousness. American Political Research 33, 521-544.

Jennings, M.K., 1983. Gender roles and inequalities in political participation: results from an eight-nation study. Western Political Quarterly 36 , 364-385.

Jennings, M.K., van Deth, J.W., Barnes, S., Fuchs, D., Heunks, F., Inglehart, R., Kaase, M., Klingemann, H.-D., Thomassen, J., 1989. Continuities in political action: a longitudinal study of political orientations in three Western democracies. De Gruyter, New York, NY.

Jeung, R., Chen, C., Park, J.Z., 2012. Introduction: religious, racial and ethnic identities of the new second generation. In: Chen, C., Jeung, R. (Eds.), Sustaining Faith Traditions in America: Race, Ethnicity, and Religion Among the Latino and Asian American Second Generation. NYU Press, New York, NY, pp. 1-22.

Jones-Correa, M., Leal, D., 2001. Political participation: does religion matter? Political Research Quarterly 54, 751-770.

Jowell, R., Roberts, C., Fitzgerald, R., Gillian, E., 2007. Measuring Attitudes Cross-nationally: Lessons from the European Social Survey. Sage, London.

Just, A., Anderson, C.J., 2012. Immigrants, citizenship, and political action. British Journal of Political Science 42, $481-509$.

Kaase, M., 1989. Mass participation. In: Jennings, M.K., van Deth, J.W. (Eds.), with Barnes, S.H., Fuchs, D., Heunks, F.J., Inglehart, R., Kaase, M., Klingemann, HD., Thomassen, J. Continuities in Political Action: A Longitudinal Study of Political Orientations in Three Western Democracies. de Gruyter, Berlin/New York.

Kalyvas, S., 1996. The rise of Christian democracy in Europe. Cornell Univeristy Press, Ithaca, NY.

Kitschelt, H., 1986. Political opportunity structures and political protest: anti-nuclear movements in four democracies. British Journal of Political Science 16, $57-85$.

Kittilson, M.C., 2009. Research resources in comparative political behavior. In: Dalton, R.J., Klingemann, H.-D. (Eds.), The Oxford Handbook of Political Behavior. Oxford University Press, Oxford, pp. 865-895.

Klausen, J., 2005. The Islamic Challenge. Oxford University Press, Oxford, Politics and religion in Western Europe.

Knutsen, O., 2004. Religious denomination and party choice in western Europe: a comparative longitudinal study from eight countries, $1970-97$. International Political Science Review 25, 97-128.

Koenig, M., 2005. Incorporating Muslim migrants in western nation states. A comparison of the United Kingdom, France, and Germany. Journal of International Migration and Integration 6, 219-234.

Kurien, P., 2005. Being young, brown, and Hindu: the identity struggles of second-generation Indian Americans. Journal of Contemporary Ethnography 34, 434-469.

Laurence, J., 2006. Managing transnational Islam: Muslims and the state in Western Europe. In: Parsons, C., Smeeding, T. (Eds.), Immigration and the transformation of Europe. Cambridge University Press, Cambridge, pp. 253-275.

Leighley, J., 1995. Attitudes, opportunities, and incentives: a field essay on political participation. Political Research Quarterly 48, $181-209$.

Lemaitre, G., Thoreau, C., 2006. Estimating the Foreign Born Population on Current Basis. Unpublished manuscript, Organization for Economic Co-operation and Development, Paris.

Liang, Z., 1994. Social contact, social capital and the naturalization process: evidence from six immigrant groups. Social Science Research 23, 407-437.

Lijphart, A., 1979. Religious vs. linguistic vs. class voting: the "crucial experiment" of comparing Belgium, Canada, South Africa, and Switzerland. American Political Science Review 73, 442-457.

Lipset, S.M., 1994. The social requisites of democracy revisited. American Sociological Review 59, 1-22.

Lipset, S.M., Rokkan, S., 1967. Party Systems and Voting Alignments. Free Press, New York.

Maussen, M., 2007. The governance of Islam in Western Europe: a state of the art report. IMISCOE working paper No.16, IMES/University of Amsterdam. <http://www.flw.ugent.be/cie/documenten/GovernanceofIslam.pdf>.

Maxwell, R., 2010. Evaluating migrant interaction: political attitudes across generations in Europe. International Migration Review 44, 25-52.

McCarthy, J., Zald, M., 1977. Resource mobilization and social movements: a partial theory. American Journal of Sociology $82,1212-1241$.

McAdam, D., 1982. Political Process and the Development of Black Insurgency, 1930-1970. University of Chicago Press, Chicago, IL.

McAdam, D., McCarthy, J.D., Zald, M.N. (Eds.), 1996. Comparative Perspectives on Social Movements: Political Opportunities, Mobilizing Structures, and Cultural Framings. Cambridge University Press, Cambridge, MA, MA.

McAdam, D., Tilly, C., Tarrow, S., 2010. The Dynamics of Contention. Cambridge University Press, Cambridge, MA.

McVeigh, R., Sikkink, D., 2001. God, politics, and protest: religious beliefs and the legitimation of contentious tactics. Social Forces 79, $1425-1458$.

Meyer, D.S., 2004. Protest and political opportunities. Annual Review of Sociology 30, 125-145.

Meyer, D.S., 2006. The politics of protest: social movements in America. Oxford University Press, New York, NY.

Meyer, D.S., Tarrow, S., (Eds.), 1998. The Social Movement Society. Rowman and Littlefield.

Milbrath, L., Goel, M.L., 1977. Political Participation: How and Why do People get Involved in Politics?, 2nd ed University Press of America, New York.

Miller, W.E., Shanks, J.M., 1996. The new American voter. Harvard University Press, Cambridge, M.A..

Minkenberg, M., 2010. Party politics, religion and elections in western democracies. Comparative European Politics 8, $385-414$.

Muller, E.N., 1977. Behavioral correlates of political support. American Political Science Review 71, $454-467$.

Muller, E.N., 1979. Aggressive Political Participation. Princeton University Press, Princeton, NJ.

Nie, N.H., Verba, S., Kim, J.-O., 1971. The modes of Democratic Participation: A Cross-National Comparison. Sage Publications, Beverly Hills, CA.

Nielsen, J.S., 1999. Towards a European Islam. Palgrave Macmillan Press.

Niessen, J., Huddleston, T., Citron, L., 2007. Migrant Integration Policy Index. British Council and Migration Policy Group, Brussels.

Norris, P., 2002. Democratic Phoenix: Reinventing Political Activism. Cambridge University Press, Cambridge, MA.

Olson, M., 1971. The Logic of Collective Action. Harvard University Press, Cambridge, MA.

Open Society Foundation, 2011. Unveiling the Truth. Why 32 Muslim Women Wear the Full-face Veil in France. At Home in Europe Project.

Peek, L., 2005. Becoming Muslim: the development of religious identity. Sociology of Religion 66, $215-242$.

Permoser, J.M., Rosenberger, S., Stoeckl, K., 2010. Religious organizations as political actors in the context of migration: Islam and orthodoxy in Austria. Journal of Ethnic and Migration Studies 36, 1463-1481.

Peterson, S.A., 1992. Church participation and political participation: the spillover effect. American Politics Quarterly $20,123-139$.

Pew Research Center, 2011. The Future of the Global Muslim Population. The Pew Forum report on religion \& public life.

Portes, A., Rumbaut, R.G., 2001. Legacies: The Story of The Immigrant Second Generation. University of California Press, Berkeley.

Portes, A., Zhou, M., 1993. The new second generation: segmented assimilation and its variants. Annals of the American Academy of Political and Social Science 53, 74-97.

Ramadan, T., 2004. Western Muslims and the future of Islam. Oxford University Press, New York.

Ramakrishnan, K.S., 2005. Democracy in Immigrant America: Changing Demographics and Political Participation. Stanford University Press, Stanford, CA. 
Rosenstone, S.J., Hansen, M., 1993. Mobilization, Participation, and Democracy in America. Macmillan, New York, NY.

Sandovici, M.E., Listhaug, O., 2010. Ethnic and linguistic minorities and political participation in Europe. International Journal of Comparative Sociology 51, $111-136$.

Scheve, K., Stasavage, D., 2006. Religion and preferences for social insurance. Quarterly Journal of Political Science 1, $255-286$.

Schmitt, M.T., Branscombe, N.R., 2002. Meaning and consequences of perceived discrimination in advantaged and privileged social groups. European Review of Social Psychology 12, 167-199.

Shingles, R.D., 1981. Black consciousness and political participation: the missing link. American Political Science Review 75, 76-91.

Snijders, T.A.B., Bosker, R., 1999. Multilevel Analysis: An Introduction to Basic and Advanced Multilevel Modeling. Sage Publications, Thousand Oaks, CA. Steenbergen, M.R., Jones, B.S., 2002. Modeling multilevel data structures. American Journal of Political Science 46, $218-237$.

Van Aelst, P., Walgrave, S., 2001. Who is that (wo)man in the street? From the normalisation of protest to the normalisation of the protester. European Journal of Political Research 39, 461-486.

Verba, S., Nie, N.H., 1972. Participation in America. Harper \& Row, New York, NY.

Verba, S., Nie, N.H., Kim, J.-O., 1978. Participation and Political Equality. Cambridge University Press, Cambridge, MA.

Verba, S., Schlozman, K.L., Brady, H.E., 1995. Voice and Equality. Civic Voluntarism in American Politics. Harvard University Press, Cambridge, MA.

Verkuyten, M., Yildiz, A.A., 2007. National (dis)identification and ethnic and religious identity: a study among Turkish Dutch Muslims. Personality and Social Psychology Bulletin 33, 1448-1462.

Voas, D., Fleischmann, F., 2012. Islam moves west: religious change in the first and second generations. Annual Review of Sociology 38 , $525-545$.

Voicu, B., Şerban, M., 2012. Immigrant involvement in voluntary associations in Europe. Journal of Ethnic and Migration Studies 38, $1569-1587$.

Wald, K.D., Wilcox, C., 2006. Getting religion: has political science rediscovered the faith factor? American Political Science Review 100, 523-529.

Wald, K.D., Silverman, A.L., Fridy, K., 2005. Making sense of religion in political life. Annual Review of Political Science 8, $121-143$.

Welzel, C., Deutsch, F., 2011. Emancipative values and nonviolent protest: the importance of 'ecological' effects. British Journal of Political Science 42, 465479.

White, S., Nevitte, N., Blais, A., Gidengil, E., Fournier, P., 2008. The political resocialization of immigrants. Political Research Quarterly 61, 268-281.

Wolfinger, R.E., Rosenstone, S.J., 1980. Who Votes? Yale University Press, New Haven, CT.

Wright, M., Bloemraad, I., 2012. Is there a trade-off between multiculturalism and socio-political integration? Policy regimes and immigrant incorporation in comparative perspective. Perspectives on Politics 10, 77-95.

Ysseldyk, R., Matheson, K., Anisman, H., 2010. Religiosity as identity: toward an understanding of religion from a social identity perspective. Personality and Social Psychology Review 14, 60-71. 